\title{
Ice nucleating particles from multiple aerosol sources in the urban environment under mixed-phase cloud conditions
}

\author{
Cuiqi Zhang ${ }^{1}$, Zhijun $\mathrm{Wu}^{1,2}$, Jingchuan Chen $^{1}$, Jie Chen ${ }^{1, a}$, Lizi Tang ${ }^{1}$, Wenfei Zhu ${ }^{1}$, Xiangyu Pei ${ }^{4}$, Shiyi
}

${ }^{1}$ State Key Joint Laboratory of Environmental Simulation and Pollution Control, College of Environmental Sciences and Engineering, Peking University, Beijing, 100871, China

${ }^{2}$ Collaborative Innovation Center of Atmospheric Environment and Equipment Technology, Nanjing University of Information Science and Technology, Nanjing 210044, China

$10 \quad{ }^{3}$ Institute for Atmospheric and Climate Science, ETHZ, Zurich, 8092, Switzerland

${ }^{4}$ College of Environmental and Resource Sciences, Zhejiang University, Hangzhou, 310058, China

${ }^{5}$ Beijing Weather Modification Center, Beijing, 100089, China

anow at: Institute for Atmospheric and Climate Science, ETHZ, Zurich, 8092, Switzerland

Correspondence to: Zhijun Wu (zhijunwu@pku.edu.cn)

15 Abstract. Ice crystals occurring in mixed-phase clouds play a vital role in global precipitation and energy balance because of the unstable equilibrium between co-existent liquid droplets and ice crystals, which affects cloud lifetime and radiative properties, as well as precipitation formation. Satellite observations proved that immersion freezing, i.e., ice formation on particles immersed within aqueous droplets, is the dominant ice nucleation (IN) pathway in mixed-phase clouds. However, the impact of anthropogenic emission on atmospheric IN in the urban environment remains ambiguous. In this study, we present

20 in situ observations of ambient ice nucleating particle number concentration $\left(N_{\mathrm{INP}}\right)$ measured at mixed-phase cloud conditions $\left(-30{ }^{\circ} \mathrm{C}\right.$, relative humidity with respect to liquid water $\left.R H_{\mathrm{w}}=104 \%\right)$ and the physicochemical properties of ambient aerosol, including chemical composition and size distribution, at an urban site in Beijing during the traditional Chinese Spring Festival. The impact of multiple aerosol sources such as firework emissions, local traffic emissions, mineral dust and urban secondary aerosols on $N_{\text {INP }}$ is investigated. The results show that $N_{\text {INP }}$ during the dust event reaches up to $160 \mathrm{Z} \mathrm{L}^{-1}$, with an activation fraction (AF) of $0.0036 \% \pm 0.0011 \%$. During the rest of the observation, $N_{\mathrm{INP}}$ is on the order of $10^{-1}$ to $10 \mathrm{Z} \mathrm{L}^{-1}$, with an average AF between 0.0001 to $0.0002 \%$. No obvious dependence of $N_{\mathrm{INP}}$ on the number concentration of particles larger than $500 \mathrm{~nm}$ $\left(N_{500}\right)$ or black carbon $(\mathrm{BC})$ mass concentration $\left(m_{\mathrm{BC}}\right)$ is found throughout the field observation. The results indicate that mineral dust dominates $N_{\mathrm{INP}}$, although the observation took place at an urban site with high background aerosol concentration. Meanwhile, the presence of atmospheric BC from firework and traffic emissions, along with urban aerosols formed via secondary transformation during heavily polluted periods do not influence the observed INP concentration. Our study corroborates previous laboratory and field findings that anthropogenic BC emission has a negligible effect on $N_{\mathrm{INP}}$, and that $N_{\text {INP }}$ is unaffected by heavy pollution in the urban environment under mixed-phase cloud conditions. 


\section{Introduction}

Mixed-phase clouds occur where super-cooled liquid water droplets co-exist with ice crystals and are normally sustained between -38 and $0{ }^{\circ} \mathrm{C}$ in the atmosphere, with ice melting rapidly at warmer temperature and droplets freezing homogeneously at colder temperature (Boucher et al., 2013; Korolev et al., 2017). The Wegener-Bergeron-Findeisen process in mixed-phase clouds favors ice crystal growth at the cost of liquid droplet evaporation (Wegener, 1911; Bergeron, 1935; Findeisen, 1938), leading to ice water content and ice crystal size change, which further result in changes of mixed-phase cloud lifetime and radiative properties, as well as global precipitation pattern (Cantrell and Heymsfield, 2005; Field and Heymsfield, 2015; Mülmenstädt et al., 2015; Korolev et al., 2017; Heymsfield et al., 2020). Satellite observations demonstrate that the predominant ice formation pathway in mixed-phase clouds is immersion freezing (e.g., Ansmann et al., 2008; de Boer et al., 2011; Silber et al., 2021). In this mode, ice nucleating particles (INPs) immersed within super-cooled aqueous droplets provide an interface that decreases the liquid-solid phase transition energy barrier and aids droplet freezing by so called heterogeneous ice nucleation (IN, Pruppacher and Klett, 2010; Vali et al., 2015; Kanji et al., 2017).

Most of the particles in highly populated urban areas originate from local emissions, including ground transportation, cooking, coal and biomass burning, leading to significant production of carbonaceous particles, including organic compounds and elemental carbon, as well as inorganic salts. Apart from local emissions, regional transportation also contributes significantly to urban particle population under appropriate meteorology conditions, during which aging can significantly modify particle physicochemical properties, such as chemical composition, morphology, and mixing state (Lin et al., 2016; Sun et al., 2016; Hua et al., 2018; Zhang et al., 2020b; Lei et al., 2021; Li et al., 2021). Previous studies have confirmed that several kinds of atmospheric particles, including mineral dusts, carbonaceous particles, and biogenic species, can act as immersion INP and catalyze ice crystal formation below $0{ }^{\circ} \mathrm{C}$ (Murray et al., 2012; Kanji et al., 2017 and references therein). The reported atmospheric INP number concentration $\left(N_{\mathrm{INP}}\right)$ were measured between $-10^{\circ} \mathrm{C}$ and $-55^{\circ} \mathrm{C}$ and were normally on the orders of $10^{-2}$ to $10^{3} \mathrm{Z} \mathrm{L}^{-1}$, which can be translated into $\sim 1$ INP out of $10^{5}$ to $10^{7}$ atmospheric particles (e.g., Rogers et al., 1998; DeMott et al., 2010; Knopf et al., 2010; Corbin et al., 2012; Chen et al., 2018; Che et al., 2019; Wolf et al., 2020b; Che et al., 2021).

Among all types of airborne particles, mineral dusts are commonly acknowledged as a major source of effective atmospheric immersion INPs (DeMott et al., 2003; Archuleta et al., 2005; Kanji and Abbatt, 2006; Welti et al., 2009; DeMott et al., 2010; Atkinson et al., 2013; Cziczo et al., 2013; DeMott et al., 2015; Chen et al., 2021). It was also reported that crystalline ammonium sulfate could nucleate ice heterogeneously below water saturation (Abbatt et al., 2006). But the effectiveness of carbonaceous particles and inorganic salts acting as INP under mixed-phase cloud conditions remains elusive (Schill et al., 2016; Chen et al., 2018; Kanji et al., 2020; Schill et al., 2020; Wolf et al., 2020a). Although certain types of black carbon (BC) and organic particles exhibited INP activity at temperatures below $-38^{\circ} \mathrm{C}$ (Murray et al., 2010; Mahrt et al., 2018; Nichman et al., 2019; Zhang et al., 2020a), field observations (Chen et al., 2018; Adams et al., 2020) and laboratory 
crystal formation via immersion mode. Besides, organic coatings are likely to impede carbonaceous particles from acting as effective INP at temperatures below $-38^{\circ} \mathrm{C}$ (Nichman et al., 2019; Zhang et al., 2020a).

Previous modelling work confirmed that anthropogenic INP emission could alter the size of ice crystals in clouds and change cloud lifetime and global precipitation pattern (Zhao et al., 2019). Yet, there is limited published direct evidence on the contribution of anthropogenic particles to ice crystal formation in highly populated areas (Knopf et al., 2010; Corbin et al., 2012; Chen et al., 2018; Che et al., 2019; Che et al., 2021). Knopf et al. (2010) used filter samples collected from a highly populated urban area in Mexico City and an optical IN microscopy technique to report that anthropogenic particles dominated by organic components might catalyze ice formation well below water saturation at temperature below $-38{ }^{\circ} \mathrm{C}$. Such organicrich anthropogenic particles also demonstrated ice formation potential via immersion pathway above $-38{ }^{\circ} \mathrm{C}$ in their study.

75 Corbin et al. (2012) suggested that coupling atmospheric dust, elemental carbon, and biomass burning particle concentration together provided the best estimation for atmospheric INP concentration in downtown Toronto at $-34{ }^{\circ} \mathrm{C}$ just below water saturation, but the share of each particle category remained unclear due to limited data. Chen et al. (2018) quantified off-line immersion INP concentration using filter samples collected every 12 hours during heavily polluted 2016 wintertime in Beijing. Even though high level $\mathrm{PM}_{2.5}$ with complex chemical composition was sampled during a heavy pollution period in the urban 80 area, these aerosols did not act as superior INPs, and the highest INP concentration measured at $-26^{\circ} \mathrm{C}$ was below 10 \# $\mathrm{L}^{-1}$, similar to what was observed in remote regions such as the Swiss Alps (Boose et al., 2016a; Lacher et al., 2017). In other words, the INP concentration reported by Chen et al. (2018) was insensitive to particle number concentration and particle chemistry in an atmosphere dominated by anthropogenic emissions. The absence of a correlation of immersion INP concentration with particle number during a pollution period was further supported by Bi et al. (2019) in an online immersion

85 INP concentration field observation at an urban site in Beijing during May to June, 2018, using a continuous flow diffusion chamber (CFDC) operated above water saturation between $-20{ }^{\circ} \mathrm{C}$ to $-30{ }^{\circ} \mathrm{C}$. However, Che et al. (2019) reported a positive correlation between the total atmospheric INP concentration and air pollution degree during springtime in Beijing. INP concentration was measured by a Bigg-mixing cloud chamber for one month in 2017, and the total atmospheric INP concentration could reach $1500 \# \mathrm{~L}^{-1}$ at $-30{ }^{\circ} \mathrm{C}$ (Che et al., 2019, 2021).

Currently, a knowledge gap still exists on the magnitude and dominant source of ambient INPs in highly populated urban area, as well as the dependence of INP concentration on anthropogenic particle emission, hampering the estimation of global atmospheric INP concentrations (Boucher et al., 2013; Seinfeld and Pandis, 2016). In this paper, we report the in situ INP concentration measured at mixed-phase clouds condition $\left(-30{ }^{\circ} \mathrm{C}\right.$, relative humidity with respect to liquid water of $104 \% R H_{\mathrm{w}}$ $=104 \%$ ) during the traditional Chinese Spring Festival at an urban site in Beijing. The correlations between immersion INP concentration, meteorology condition, and aerosol physiochemical properties are also explored. 


\section{Methods}

\subsection{Sampling}

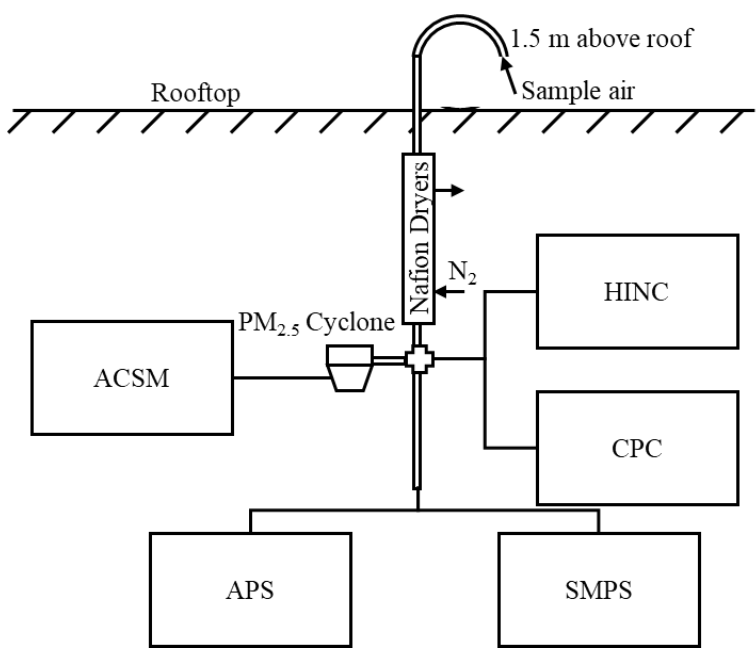

Figure 1: Schematic of the sampling and experimental setup (not drawn to scale).

The sampling site $\left(39^{\circ} 59^{\prime} 20^{\prime \prime} \mathrm{N}, 116^{\circ} 18^{\prime} 26^{\prime \prime} \mathrm{E}\right)$ is located on the roof of a six-floor building ( 30 m above ground level) at Peking University, which is adjacent to the north-western $4^{\text {th }}$ ring road of Beijing. The site lies about $250 \mathrm{~m}$ west of a busy street with heavy traffic. At the sampling site, meteorological parameters, including wind speed, wind direction, $R H_{\mathrm{w}}$, and temperature, were measured by a weather station (MetOne Inc.). The mass concentration of particulate matter (PM) with aerodynamic diameter $\left(d_{\mathrm{a}}\right)$ smaller than 2.5 and $10 \mu \mathrm{m}\left(\mathrm{PM}_{2.5}\right.$ and $\mathrm{PM}_{10}$, respectively) were measured by a tapered element oscillating microbalance (TEOM) monitor. The temporal resolutions of meteorology and PM data were 1 minute.

Ambient air was sampled through a stainless tube with an inner diameter of $12.7 \mathrm{~mm}$. The tube inlet was bent facing downwards (see Fig. 1) to prevent water contamination and allowed particles smaller than $20 \mu \mathrm{m}$ to enter. The sample flow was then split and pumped into different instruments. The relative humidity of the sample stream $\left(R H_{\mathrm{w}}\right.$, sample $)$ was kept below

$1102 \%$ by passing through two consecutive $47 \mathrm{~cm}^{\text {Nafion }}{ }^{\mathrm{TM}}$ dryers (Perma Pure, LLC.) using 4 LPM nitrogen as sheath gas during the experiment. A schematic of the setup is shown in Fig. 1.

\subsection{Instrumentation}

\subsubsection{Particle number size distribution}

Sub-micron particle number size distribution was measured by a scanning mobility particle sizer (SMPS, model 3082,

115 comprising a 3082 classifier, a 3081 long DMA, and a 3776 CPC; TSI Inc.). The sampling flow rate of SMPS was set to 0.3 LPM with a sheath-to-sample ratio of 10:1, resulting in an electrical mobility size range from $14.6 \mathrm{~nm}$ to $710.5 \mathrm{~nm}$. 
An aerodynamic particle sizer (APS, model 3021; TSI Inc.) was used to provide number size distribution for ambient aerosols with $d_{\mathrm{a}}$ ranging from $0.542 \mu \mathrm{m}$ to $19.81 \mu \mathrm{m}$. The aerodynamic particle number size distribution obtained from APS could be converted to particle mobility size $\left(d_{\mathrm{m}}\right)$ distribution by assuming the effective density of ambient particles to be $1.5 \mathrm{~g}$ $\mathrm{cm}^{-3}$ (Khlystov et al., 2004; Chen et al., 2018). The total inflow rate of APS was 5 LPM, of which 1 LPM was sample flow, and a remainder 4 LPM (passing through a built-in particle filter) as a sheath flow.

\subsubsection{Particle chemical composition}

Real-time non-refractory $\mathrm{PM}_{1}\left(d_{\mathrm{a}}\right.$ smaller than $\left.1.0 \mu \mathrm{m}\right)$ mass loading and chemical composition was measured by an Aerosol Chemical Speciation Monitor (ACSM; Aerodyne Inc.) equipped with a quadrupole analyzer. The sampling flow rate of ACSM was 0.1 LPM. A PM 2.5 cyclone was installed upstream ACSM inlet to prevent inlet clog by particles with $d_{\mathrm{a}}$ larger than 2.5 $\mu \mathrm{m}$. The time resolution of an ACSM scan was set to 15 minutes. Meanwhile, BC mass concentration was monitored by a multi-angle absorption photometer (MAAP, model 5012; Thermo, Inc.) with a temporal resolution of 1 minute.

\subsubsection{Ice nucleating particle (INP) concentration}

In situ immersion INP concentration was measured by a Horizontal Ice Nucleation Chamber (HINC) at fixed lamina condition

130 throughout the observation period, i.e. with a lamina temperature $\left(\underline{T}_{\text {lam }}\right)$ of $-30{ }^{\circ} \mathrm{C}$ and $R H_{\mathrm{w}}=104 \%\left(\right.$ equivalent to $R H_{\mathrm{i}}=140 \%$, where the subscript i denotes ice). HINC is a CFDC type instrument made of two flat parallel copper plates. The temperature of each plate is controlled independently to create supersaturation along the chamber centerline lamina. To minimize the impact of convection, the top plate of HINC is warmer than the bottom plate. Ice crystal size and number was measured by a 6-channel optical particle counter (OPC; MetOne Inc.). The injector position, and thus the flow structure of HINC in this study is identical

135 to the setting of Lacher et al. (2017). Therefore, only particles larger than $5 \mu \mathrm{m}$ detected by the HINC OPC are counted as ice crystals. For more detailed HINC design and operating principle information, please refer to Lacher et al. (2017) and Kanji and Abbatt (2009).

In this study, both warm and cold walls of HINC lined with glass-fiber filter paper were wetted with $\sim 150 \mathrm{~mL}$ de-ionized water each day before the experiment start, or after running experiment for 4 hours. After draining for $\sim 15$ min, the wall temperatures of warm and cold walls would be set to -20 and $-40{ }^{\circ} \mathrm{C}$ respectively to achieve desired lamina temperature ($30{ }^{\circ} \mathrm{C}$ ) and $R H_{\mathrm{w}}(104 \%)$. The sampling flow rate of HINC was 0.26 LPM, surrounded by 2.57 LPM particle-free nitrogen sheath gas. During the experiment, sampling air would pass through a particle filter for 5 minutes after every 15 minutes of measurement to quantify HINC background count detected by the OPC. HINC background counts follow a Poisson distribution, based on which the average background count is determined. Average ice crystal concentration (equivalent to $N_{\text {INP) }}$ of the $15-$ minute measurement is calculated by firstly subtracting the average background particle counts from measurement counts, and secondly converting particle counts to number concentration using HINC sampling flowrate. This study reports positive $N_{\text {INP }}$ only, because the negative values indicate that the signal of OPC during the measurement is undistinguishable from background noise. 
Ambient particle number concentration entering HINC was monitored by a CPC (Model 3775; TSI Inc.) connected in parallel with HINC at the aerosol inlet (see Fig. 1). Activation fraction (AF), i.e. the ratio between ice crystal number concentration at HINC outlet (calculated from OPC counts, as stated above) and total particle number concentration at HINC inlet (measured by CPC) were simultaneously monitored and calculated.

\section{Results and discussion}

\subsection{Overview}

155 The observation lasted from Feb. $10^{\text {th }}$ to $28^{\text {th }}$, overlapping with the traditional Chinese Spring Festival for the year 2021 . Figure 2 displays the chemical composition of non-refractory $\mathrm{PM}_{1}$ mass concentration in the upper panel, and particle number size distribution in the lower panel. Figure 3 shows the ambient meteorology conditions, including wind speed, wind direction, temperature, and $R H_{\mathrm{w}}$ in the upper and middle panels, respectively. $\mathrm{PM}_{2.5}$ and $\mathrm{PM}_{10}$ mass concentrations are shown in the lower panel of Fig. 3. In addition to $N_{\mathrm{INP}}$, Fig 4 also presents the BC mass concentration $\left(m_{\mathrm{BC}}\right)$ variation during the observation.

160 The grey shading in Fig. 2-4 indicates the IN experiment time periods.
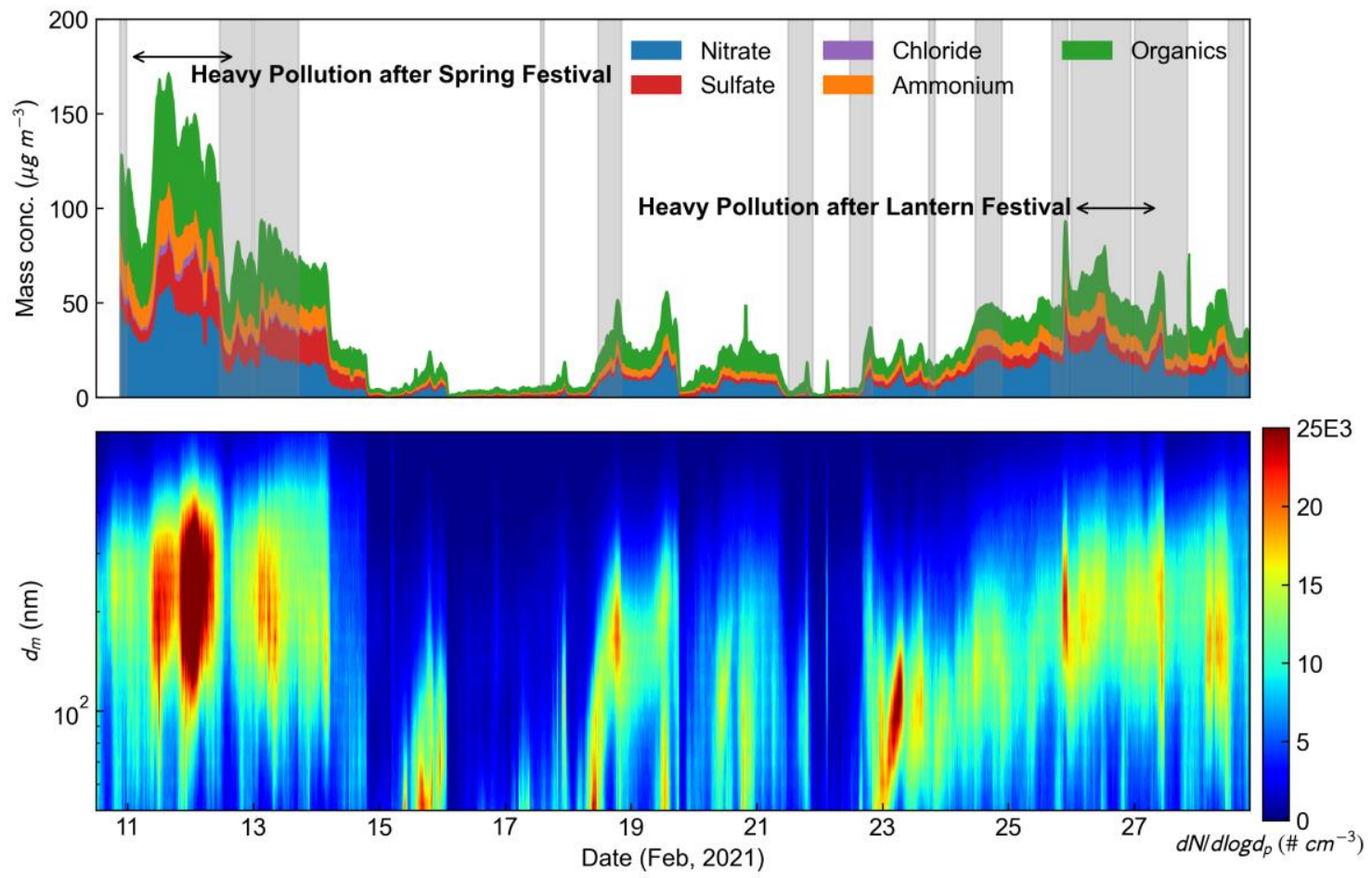

Figure 2: Time series of non-refractory $\mathrm{PM}_{1}$ mass concentration (upper panel) and particle number size distribution (lower panel). The grey shading and black arrows in the upper panel indicate IN experiment time periods and heavy pollution after celebrations, respectively 

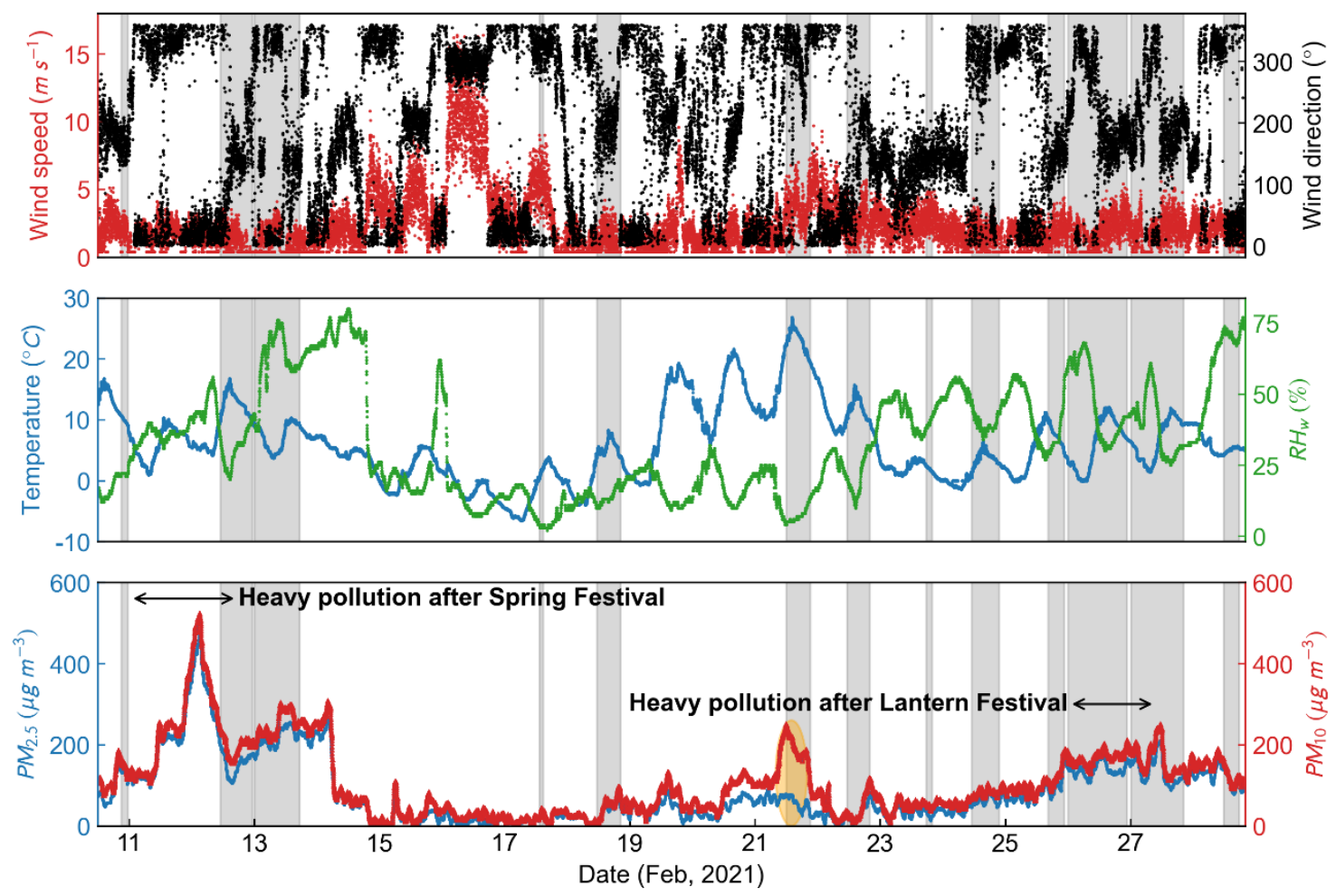

Figure 3: Times series of wind speed and direction (upper panel), ambient temperature and relative humidity with respect to liquid water $\left(\mathrm{RH}_{\mathrm{w}}\right.$, middle panel), and $\mathrm{PM}_{2.5}$ and $\mathrm{PM}_{10}$ mass concentration (lower panel). The grey shading in each panel indicates IN experiment time periods; the orange shading and arrows in the lower panel mark the dust event on Feb. $21^{\text {st }}, 2021$ and the heavy pollution after celebrations, respectively.

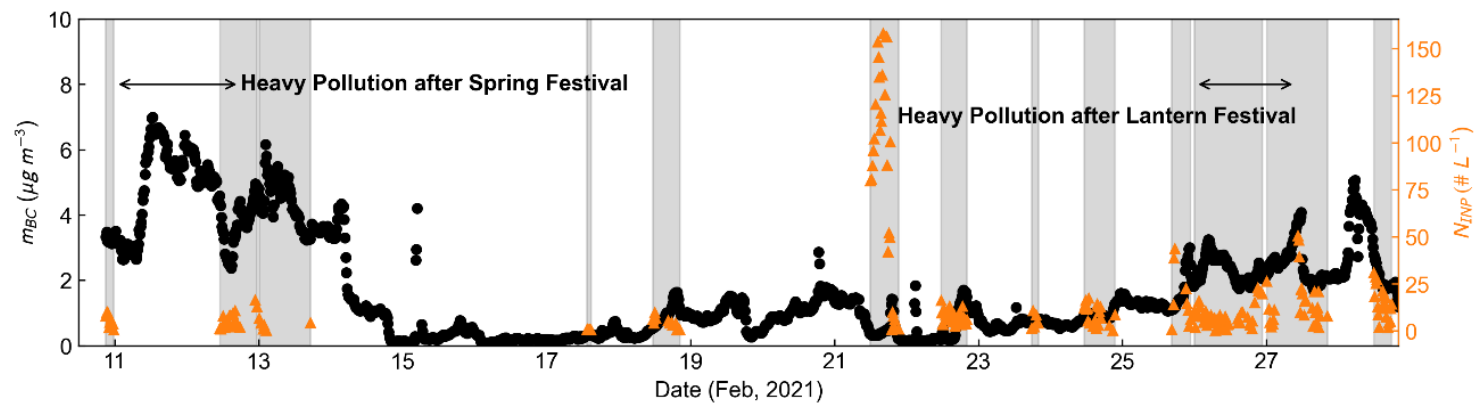

Figure 4: Time series of black carbon (BC) particle mass concentration $\left(m_{\mathrm{BC}}\right)$ and INP number concentration $\left(N_{\mathrm{INP}}\right)$. The arrows indicate the heavy pollution after celebrations.

On Feb. $11^{\text {th }}$ and $26^{\text {th }}$ night, fireworks were lit for celebrations of the Spring and Lantern Festivals. Large amounts of particles emerged after the celebrations due to firework emission, as indicated by the sharp growth of non-refractory $\mathrm{PM}_{1}$ mass concentration comprising organic components and chloride salts in the upper panel of Fig. 2 . Up to $7 \mu \mathrm{g} \mathrm{m}^{-3}$ of BC particles mainly originating from firework emission were also detected during and after the celebrations, as illustrated in Fig. 4. Apart from the firework emission, the mass concentration of nitrate and sulfate also increased significantly (upper panel of Fig. 2) 
under the relatively stagnant and humid meteorological conditions after Feb. $11^{\text {th }}$ and $26^{\text {th }}$ nights (middle panel of Fig. 3), indicating secondary pollutant formation (e.g., Wu et al., 2018). Such secondary pollutant transformation processes produce particles in the accumulation mode, as illustrated by the high level of particle concentration peaking between 200-300 nm in Fig. 2. During heavy pollution after the Spring and Lantern Festivals, $\mathrm{PM}_{2.5}$ mass concentration respectively approached $\sim 550$ and $200 \mu \mathrm{g} \mathrm{m}^{-3}$ (lower panel of Fig. 3). The synergetic heavy pollution induced by secondary pollutant formation and firework emission are marked with arrows in Fig. 2-4.

On Feb. $18^{\text {th }}$, the first workday after the Spring Festival holiday (Feb. $11^{\text {th }}$ to Feb. $17^{\text {th }}$ ), people swarmed into downtown

185 Beijing and the mass concentrations of non-refractory $\mathrm{PM}_{1}$ and $\mathrm{PM}_{2.5}$ increased during rush hours, as can be seen in Fig. 2 and 3 , respectively. $m_{\mathrm{BC}}$ also increased because of increasing use of passenger vehicles during rush hours on workdays after Feb. $18^{\text {th }}$, as shown in Fig. 4.

During the whole observation, there was minor difference between ambient $\mathrm{PM}_{2.5}$ and $\mathrm{PM}_{10}$ mass concentrations except for Feb. $21^{\text {st }}$ afternoon, when there was a significant increase of $\mathrm{PM}_{10}$ mass concentration as highlighted by the orange shading in Fig. 3, implying that large (dust) particles with $d_{\mathrm{a}}$ ranging between $2.5 \mu \mathrm{m}$ and $10 \mu \mathrm{m}$ were present. Besides, aerodynamic particle number size distribution exhibited a clear shift towards the larger end during the dust event (Fig. A1) with a mode size around $1 \mu \mathrm{m}$, which further confirmed the presence of large particle during the dust event. Aerosol optical depth (AOD) derived from MODIS Aqua Deep Blue Collection 6 dataset at $550 \mathrm{~nm}$ (Acker and Leptoukh, 2007) also shows elevated aerosol loading on Feb. $21^{\text {st }}$ afternoon at the sampling site compared to Feb. 20 ${ }^{\text {th }}$ (Fig. A2). Based on measured particle mass concentration level and meteorology conditions, the observation days are categorized into different scenarios, i.e. dust event, clean, and heavy pollution days, as summarized in Table 1.

Table 1 The date, number concentrations of immersion INP $\left(N_{\mathrm{INP}}\right)$, ambient particle $\left(N_{\mathrm{CPC}}\right)$, particles larger than $500 \mathrm{~nm}\left(N_{500}\right)$ and $1000 \mathrm{~nm}\left(N_{1000}\right)$, as well as mass concentrations of BC particles $\left(m_{\mathrm{BC}}\right)$ and ammonium salt $\left(m_{\mathrm{ammo}}\right)$, and activation fraction $(\mathrm{AF})$ for each scenario. The numbers are average values, and numbers in parentheses denote one standard deviation ( $\sigma)$ from the average.

\begin{tabular}{lllllllll}
\hline Scenario & Date of Feb. & $N_{\mathrm{INP}}\left(\# \mathrm{~L}^{-1}\right)$ & $N_{\mathrm{CPC}}\left(\# \mathrm{~cm}^{-3}\right)$ & $N_{500}\left(\# \mathrm{~cm}^{-3}\right)$ & $m_{\mathrm{BC}}\left(\mu \mathrm{g} \mathrm{m}^{-3}\right)$ & $m_{\mathrm{ammo}}\left(\mu \mathrm{g} \mathrm{m}^{-3}\right)$ & $\mathrm{AF}(\%)$ & $\mathrm{PM}_{2.5}\left(\mu \mathrm{g} \mathrm{m}^{-3}\right)$ \\
\hline Dust & 21 & $112(34)$ & $3364(953)$ & $27(3)$ & $0.4(0.1)$ & $0.6(0.1)$ & $0.0036(0.0011)$ & $57(16)$ \\
Clean & $10,17-18,22$ & $5(4)$ & $5375(1443)$ & $70(75)$ & $1.1(1.0)$ & $5.1(6.2)$ & $0.0001(0.0001)$ & $50(38)$ \\
Pollution & $12-13,24-27$ & $9(9)$ & $4284(898)$ & $264(111)$ & $2.4(1.1)$ & $9.7(5.3)$ & $0.0002(0.0002)$ & $128(44)$ \\
Overall & $10-28$ & $18(32)$ & $4414(1225)$ & $191(138)$ & $1.8(1.2)$ & $7.1(5.8)$ & $0.0005(0.0010)$ & $97(53)$ \\
\hline
\end{tabular}

In the following sections, the data collected in this study is categorized into aforementioned scenarios. The correlation between $N_{\text {INP }}$ and the physiochemical properties of ambient particles, including particle number concentration and chemical composition, in each scenario and the potential source of immersion INP are discussed. We also compare to $N_{\text {INP }}$ measured under similar conditions reported in the literature, with particular attention to the magnitude of $N_{\text {INP }}$ and INP source attribution. 


\subsection{Contribution of mineral dust to $N_{\text {INP }}$ during the dust event}

On the afternoon of Feb. $21^{\text {st }}, 2021$, a dust event occurred at the sampling site, as indicated clearly by the significant difference between $\mathrm{PM}_{10}$ and $\mathrm{PM}_{2.5}$ mass concentrations in Fig. 3. $\mathrm{PM}_{10}$ mass concentration reached $250 \mu \mathrm{g} \mathrm{m}^{-3}$ and was 3 to 5 times as much as the $\mathrm{PM}_{2.5}$ mass concentration during the dust event.

The dust event is characterized with a substantially higher AF of $0.0036 \% \pm 0.0011 \%$ compared to other days, as listed in Table 1. During the dust event, $N_{\mathrm{INP}}$ was 1 to 2 orders of magnitude higher than clean days, ranging from 40 to $160 \mathrm{~L}^{-1}$. Meanwhile, the ambient particle number concentration entering HINC $\left(N_{\mathrm{CPC}}\right)$ during the dust event is only half to two thirds of the clean-day concentration level (Table 1), leading to the distinguishably higher $\mathrm{AF}$. $N_{\mathrm{INP}}$ and $\mathrm{AF}$ measured during the dust event are close to the results obtained by Ardon-Dryer and Levin (2014) around $-24{ }^{\circ} \mathrm{C}$ during east Mediterranean dust storms using droplet freezing technique. The significant increase of $N_{\mathrm{INP}}$ in the dust event complies with the results of Bi et al. (2019), who reported $N_{\mathrm{INP}}$ as high as $2800 \# \mathrm{~L}^{-1}$ measured at $-30{ }^{\circ} \mathrm{C}$ and $R H_{\mathrm{w}}=106.5 \%$ during a desert dust event at a rural sampling site in suburban Beijing. Chen et al. (2021) reported an up to $44 \mathrm{Z} \mathrm{L}^{-1}$ immersion INP number concentration for size-resolved mineral dust between $-20{ }^{\circ} \mathrm{C}$ and $-27^{\circ} \mathrm{C}$ by using an off-line cold-stage technique at the same sampling site in springtime as this study. $N_{\text {INP }}$ measured during the dust event in this study (40 to 160 \# L-1) is in line with the immersion $N_{\text {INP }}$ results of Chen et al. (2021). 24-hour back trajectory analysis at three heights (20 m, $500 \mathrm{~m}$, and $1000 \mathrm{~m}$, Fig. A3) using National Oceanic and Atmospheric Administration (NOAA) HYSPLIT model suggests that the air parcel during the dust event is from the northwestern direction of Beijing, originating from the Mongolia Gobi Desert. The back trajectory analysis by Bi et al. (2019) also suggested that air parcels from Mongolia Gobi Desert tended to carry loads of desert dust, leading to higher $N_{\text {INP. }}$.

Previous laboratory studies have shown that larger particles, especially those larger than 500 or $1000 \mathrm{~nm}$, exhibit superior

INP activity based on surface active site density theory (e.g., Connolly et al., 2009; Welti et al., 2009; Lüönd et al., 2010; Hoose and Möhler, 2012; Ardon-Dryer and Levin, 2014; Chen et al., 2021). Bi et al. (2019) observed significant increase of $N_{\text {INP }}$ when ambient particle peak size shifted towards the larger end of size spectra (exceeding $1000 \mathrm{~nm}$ ) during

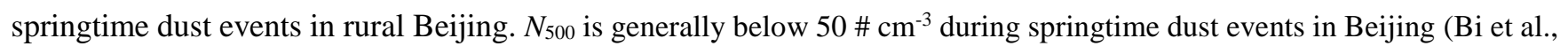
2019), and is comparable to the results presented in Fig. 5a. To quantify the impact of $N_{500}$ on $N_{\text {INP, }}$ linear regression analysis between logarithms of $N_{\mathrm{INP}}$ and $N_{500}$ is performed for dust event using ordinary least square (OLS) method, as shown in Fig. 5a. The triangles indicate measured data, and the blue markers are the predicted data using the fitted linear regression parameters. The coefficient of determination $\left(R^{2}\right)$ between $\log _{10}\left(N_{\mathrm{INP}}\right)$ and $\log _{10}\left(N_{500}\right)$ is 0.11 (Fig. 5a), reflecting that $N_{500}$ is not likely to be correlated with $N_{\mathrm{INP}}$, and might have limited impact on $N_{\mathrm{INP}}$ during the dust event. Besides, the significant difference between $\mathrm{PM}_{10}$ and $\mathrm{PM}_{2.5}$ mass concentrations (lower panel of Fig. 3) indicates that large (dust) particle (occupies high mass concentration but low number concentration) with high IN activity appeared during the dust event. It would be worthwhile to explore the connection between the mass concentration difference of $\mathrm{PM}_{10}$ and $\mathrm{PM}_{2.5}\left(\mathrm{PM}_{10-2.5}\right)$ and $N_{\mathrm{INP}}$ in the urban environment. OLS linear regression analysis between $N_{\mathrm{INP}}$ and $\mathrm{PM}_{10-2.5}$ data collected during the dust event exhibits a 
stronger yet not statistically significant correlation $\left(R^{2}=0.24\right.$, Fig. C1) compared to the correlation between $N_{\mathrm{INP}}$ and $N_{500}$. An earlier study in east Mediterranean urban region claimed that immersion IN activity of particles collected during dust storms correlated well $\left(R^{2}=0.47\right)$ with $\mathrm{PM}_{10-2.5}$ between $-10{ }^{\circ} \mathrm{C}$ and $-30{ }^{\circ} \mathrm{C}$ (Ardon-Dryer and Levin, 2014). However, the correlation between $N_{\mathrm{INP}}$ and $\mathrm{PM}_{10-2.5}$ at $-30{ }^{\circ} \mathrm{C}$ during the dust event in this study suggests that $\mathrm{PM}_{10-2.5}$ is not well correlated with $N_{\text {INP }}$ in the urban environment.
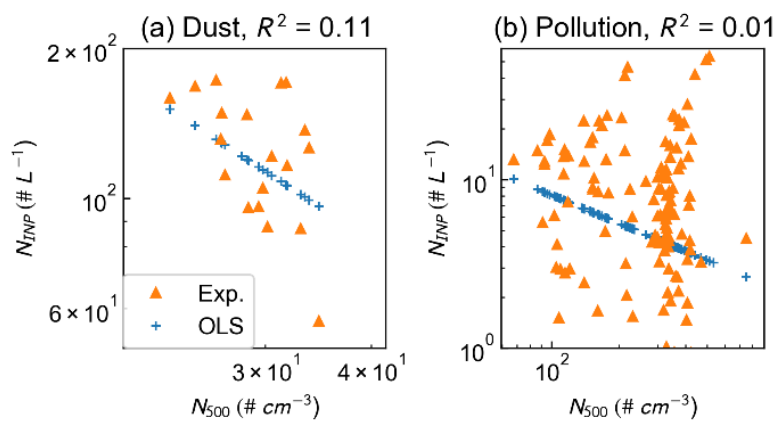

Figure 5: Correlations between $N_{500}$ and $N_{\text {INP }}$ for (a) dust event and (b) heavy pollution. $R^{2}$ above each panel is the coefficient of determination for the linear regression fitting of the experiment data using ordinary least square (OLS) method. Blue markers indicate predicted $N_{\text {INP }}$ using fitted linear regression parameters.

The upper panel of Fig. 6 displays the diurnal profile of measured $N_{\mathrm{INP}}$ and mass concentration of atmospheric ammonium ( $m_{\text {ammo }}$ ) during the dust event. It can be seen that except for 13:00 (UTC+8), $N_{\text {INP }}$ profile seems to follow $m_{\text {ammo }}$ profile. Wu et al. (2020) reported that ammonium ions could form and accumulate on mineral dust surface in the form of ammonium nitrate in the highly populated urban environment. The synchronized trends of $N_{\mathrm{INP}}$ and $m_{\text {ammo }}$ suggest that the trace amount of atmospheric ammonium (below $1 \mu \mathrm{g} \mathrm{m}^{-3}$ compared to 5-10 $\mu \mathrm{g} \mathrm{m}^{-3}$ on other days, as listed in Table 1) might be internallymixed with ambient mineral dust particles. The ammonium content on mineral dust surface might promote their IN activity due to strengthened ammonium ion surface adsorption followed by the formation of ice-favorable structure on dust particle surfaces (Boose et al., 2016b; Kumar et al., 2018; Whale et al., 2018; Kumar et al., 2019). To quantify the correlation between atmospheric ammonium content and $N_{\mathrm{INP}}$ during the dust event, and to investigate whether the observed enhancement of mineral dust IN activity by ammonium salts in previous studies (Boose et al., 2016b; Kumar et al., 2018; Whale et al., 2018; Kumar et al., 2019) still holds for the urban environment, linear regression analysis between $N_{\mathrm{INP}}$ and $m_{\text {ammo }}$ is performed, as shown in the lower panel of Fig. 6 . The blue markers are fitted $N_{\text {INP }}$ based on the OLS regression parameters, and the blue

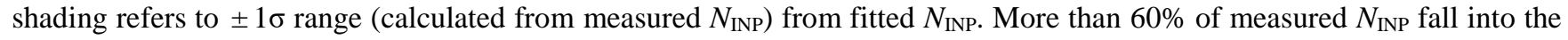
shaded area, suggesting that $N_{\mathrm{INP}}$ might be associated with $m_{\mathrm{ammo}}$ during dust events in the urban environment. However, more field observations in urban areas, as well as systematic laboratory studies using natural mineral dust samples (e.g., Saharan dust and Asian dust, etc.) are required to further investigate the connection between mineral dust surface characteristics and IN activity, and the underlying mechanism. 

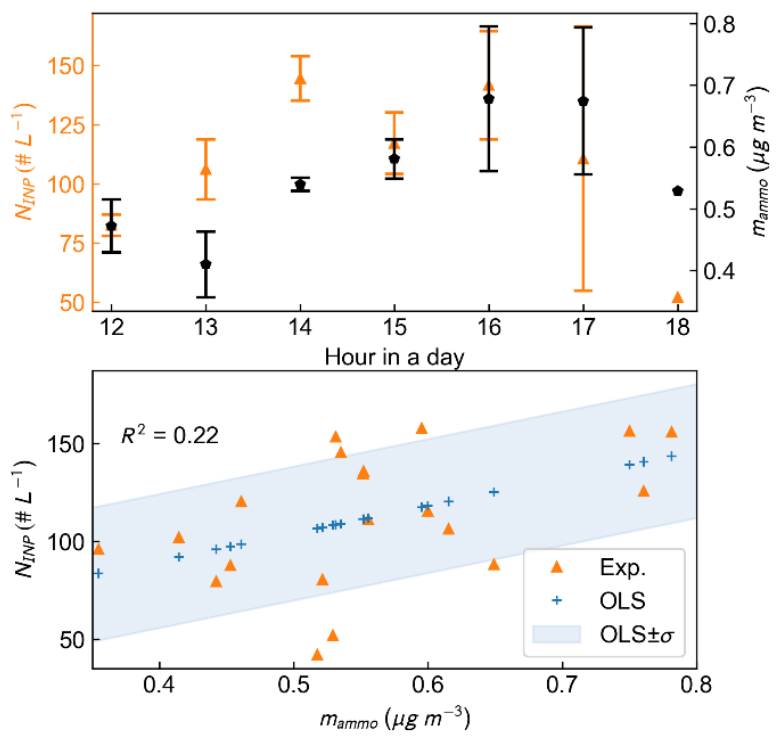

265 Figure 6: Diurnal profile of (upper panel) and correlation between (lower panel) $N_{\mathrm{INP}}$ and $m_{\text {ammo }}$ during the dust event. The blue markers in the lower panel indicate the predicted $N_{\mathrm{INP}}$ using fitted linear regression parameters. The blue shading indicates $\pm 1 \sigma$ of measured $N_{\text {INP }}$ from predicted $N_{\text {INP. }}$

$N_{\text {INP }}$ measured during the dust event are compared with previous empirical parameterizations with a particular focus on mineral dusts to link parameterizations with the observation and gain better insight into the deviation between measured and predicted $N_{\mathrm{INP}}$. Almost all measured $N_{\mathrm{INP}}$ lie within a factor of 2.5 of the predicted $N_{\mathrm{INP}}$ using the widely-used parameterization proposed by DeMott et al. (2010) based on 14-year field observation data, as shown by the brown squares and shading in Fig. 7. This parameterization links $N_{\mathrm{INP}}$ at a specific temperature with the exponential form of $N_{500}$ and takes not just mineral dusts but all ambient IN active aerosol types into consideration. It should be noted that most measured $N_{\text {INP }}$ lie above the DeMott et al. (2010) parameterization predicted $N_{\mathrm{INP}}$. Such underestimation by DeMott et al. (2010) parameterization for ammoniumrich mineral dusts was also reported earlier in a Saharan dust plume observation, and was attributed to not taking the IN activity enhancement of mineral dusts by trace amount atmospheric ammonium into consideration (Boose et al., 2016b). Another empirical $N_{\text {INP }}$ parameterization proposed by DeMott et al. (2015) is specifically for mineral dusts based on laboratory measurement. However, it tends to systematically overestimate $N_{\mathrm{INP}}$ during the dust event by up to an order of magnitude (3 to 13 times higher than the measured values) as shown by the blue squares in Fig. 7. Such overestimation suggests that $N_{\text {INP }}$ parameterization based on laboratory results might overestimate the importance of mineral dusts in the urban environment, and therefore could represent the upper limit of atmospheric INP number concentration in global models. 


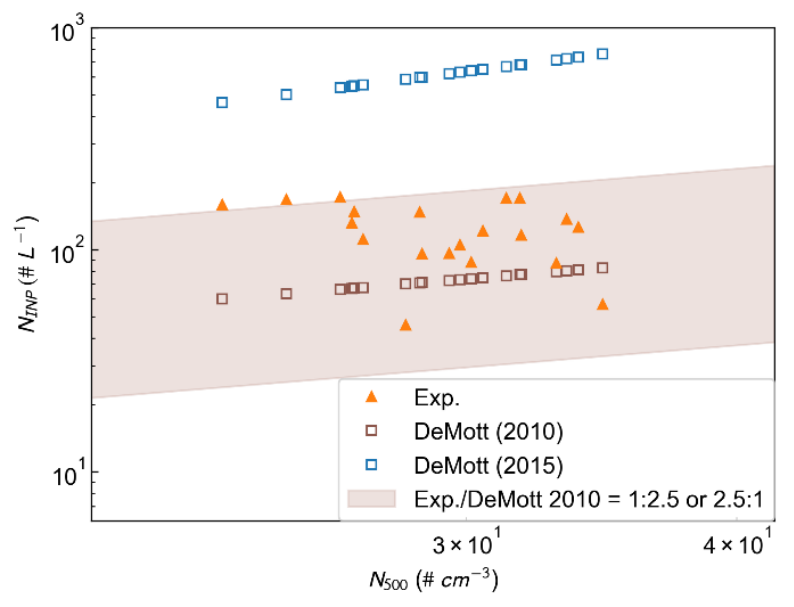

Figure 7: Inter-comparison of measured (solid orange triangles) and predicted (hollow blue and brown squares) $N_{\text {INP }}$ during the dust event. The prediction is based on the parameterizations that link $N_{\text {INP }}$ with the number concentration of particles larger than $500 \mathrm{~nm}\left(N_{500}\right)$ at a specific temperature (DeMott et al., 2010; DeMott et al., 2015).

\subsection{Contribution of black carbon (BC) to $N_{\mathrm{INP}}$}

\subsubsection{Traffic emission}

Clean days, when compared with heavy polluted or dusty days, provide ideal background to investigate the impact of primary particle emission sources, especially local traffic emission (from clean days), on $N_{\mathrm{INP}}$ in urban regions. The major particle formation pathway in gasoline passenger vehicle exhausts is volatile organic compound (VOC) nucleation, producing large number of nanoparticles (diameter smaller than $50 \mathrm{~nm}$ ) with low mass concentration (Raza et al., 2018 and references therein). On the other hand, diesel engine particle emission is dominated by BC particles ranging between 80-200 nm (Kittelson, 1998). The increase of mass concentrations of organics $\left(m_{\text {org }}\right)$ and BC between 16:00 to 20:00 (UTC+8) in Fig. 8 corresponds to the evening rush hours, during which the emission of gasoline passenger vehicles dominating ambient particle population in the urban region. There is a further increase of $m_{\mathrm{Org}}$ and $m_{\mathrm{BC}}$ after 20:00 (UTC+8) followed by a plateau in Fig. 8. According to Beijing municipal administrative regulation, heavy-duty diesel trucks for goods transportation, as well as gasoline passenger vehicles with foreign plates (issued by cities other than Beijing) are only permitted to enter urban Beijing after 20:00 (UTC+8). Increasing emission from on-road heavy-duty diesel trucks and gasoline passenger vehicles with foreign plates are highly likely to be responsible for the increasing $m_{\mathrm{Org}}$ and $m_{\mathrm{BC}}$ after 20:00 (UTC+8, Hua et al., 2018; Zhang et al., 2019). 


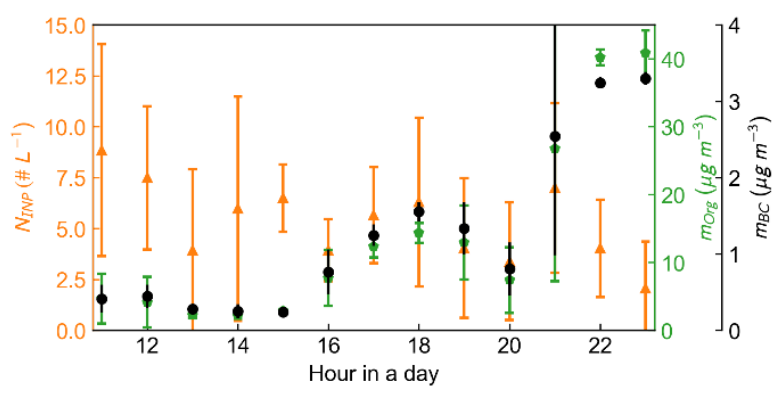

Figure 8: Mass concentration of organics $\left(m_{\mathrm{org}}\right)$ and $\mathrm{BC}\left(m_{\mathrm{BC}}\right)$ on clean days.

$N_{\text {INP }}$ of clean days ranges between 0.33 to $16 \#^{-1}$ which is the same order of magnitude as the immersion $N_{\text {INP }}$ results of Schill et al. (2016), who reported $N_{\mathrm{INP}}$ for both freshly-emitted and aged $\mathrm{BC}$ on the orders of $10^{-1}$ to $10^{1} \# \mathrm{~L}^{-1}$ measured at similar experiment condition $\left(-30{ }^{\circ} \mathrm{C}\right.$ and $\left.R H_{\mathrm{w}}=105 \%\right)$ to this study, using $\mathrm{BC}$ generated from an off-road diesel engine. To investigate the impact of traffic emission on $N_{\mathrm{INP}}$, linear regression analysis is performed between $N_{\mathrm{INP}}$ and $m_{\mathrm{BC}}$, a widely used cursor of traffic emission. As shown in Fig. 9a, the correlation between $N_{\mathrm{INP}}$ and $m_{\mathrm{BC}}$ is poor $\left(R^{2}=0.01\right)$, implying that $N_{\mathrm{INP}}$ is independent of $m_{\mathrm{BC}}$ on clean days. Recently, Kanji et al. (2020) also reported that BC might not act as effective immersion INP based on laboratory experiments. The absence of a relationship between $N_{\mathrm{INP}}$ on $m_{\mathrm{BC}}$ on clean days in this study is consistent with previous findings (Schill et al., 2016; Kanji et al., 2020; Schill et al., 2020).
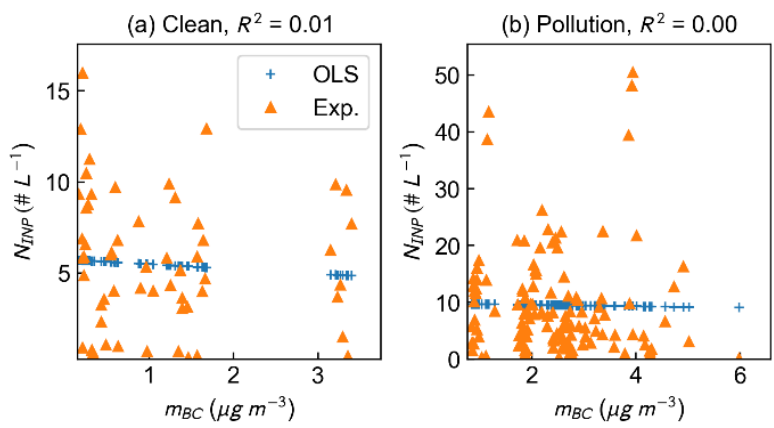

Figure 9: Correlations between $m_{\mathrm{BC}}$ and $N_{\mathrm{INP}}$ during (a) clean and (b) heavy pollution periods. $\boldsymbol{R}^{2}$ above each panel is the coefficient of determination for the linear regression fitting of the experiment data using OLS method. Blue markers indicate the predicted $N$ INP using fitted linear regression parameters.

\subsubsection{Firework emission}

315 Heavy pollution accompanied by the presence of substantially higher mass concentrations of non-refractory $\mathrm{PM}_{1}, \mathrm{PM}_{2.5}(128$ $\pm 44 \mu \mathrm{g} \mathrm{m}^{-3}$ ) and BC (up to $6 \mu \mathrm{g} \mathrm{m}^{-3}$ ) occurred during Feb. 12-13 and 24-27, as shown in Fig. 2-4. $N_{500}$ was also substantially higher during heavy pollution than other days (Table 1). As stated above, large amounts of particles comprising carbonaceous material and chloride emerged after Spring and Lantern Festival celebrations due to firework emissions which also contain trace amounts of potassium and other metal elements (Jiang et al., 2015; Kong et al., 2015; Cao et al., 2017). 
With almost 10 times as much $N_{500}$ as that of the dust event during heavy pollution, it was expected that a substantially higher INP concentration should be observed if these large particles are effective INP. However, the particle population during heavy pollution did not exhibit superior IN activity, with the majority of $N_{\mathrm{INP}}$ fell into the range of 0 to $25 \mathrm{\#} \mathrm{L}^{-1}$. As shown in Fig. $5 \mathrm{~b}$ and Fig. 9b, the OLS linear regression results further suggest that $N_{\mathrm{INP}}$ is likely to be independent of $N_{500}$, as well as $m_{\mathrm{BC}}$ during heavily polluted days, with $R^{2}$ between $\log _{10}\left(N_{\mathrm{INP}}\right)$ and $\log _{10}\left(N_{500}\right), m_{\mathrm{BC}}$ being 0.01 and 0 , respectively. The independence of $N_{\mathrm{INP}}$ on $m_{\mathrm{BC}}$ is compliant with the results of Adams et al. (2020), in which there was a substantial growth (by more than an order of magnitude) of ambient particle number concentration and $m_{\mathrm{BC}}$ from combustion and firework emissions, but no significant $N_{\text {INP }}$ change was observed. Chen et al. (2018) conducted off-line $N_{\text {INP }}$ measurement using filtered samples collected at the same sampling site as this study during heavy pollution, and found no dependence of $N_{\text {INP }}$ on neither the mass concentrations of $\mathrm{PM}_{2.5}$ and $\mathrm{BC}$, nor $N_{500}$ as well. As aforementioned, the synergetic heavy pollution after festival celebrations were induced by secondary pollutant formation via liquid phase reaction (Wang et al., 2018; Wu et al., 2018) and firework emission. Under the mixed-phase cloud condition $\left(-30^{\circ} \mathrm{C}, R H_{\mathrm{w}}=104 \%\right)$ in this study, such particles are very likely to become aqueous droplets or contain liquid films on solid particles, which might require conditions for homogeneous freezing to nucleate ice.

\section{Conclusion}

335 Continuous in situ observation of INP number concentration $\left(N_{\mathrm{INP}}\right)$ and physiochemical properties, including chemical composition and size distribution, of ambient particles at an urban site in Beijing during the traditional Chinese Spring Festival has been performed at mixed-phase cloud condition $\left(-30{ }^{\circ} \mathrm{C}, R H_{\mathrm{w}}=104 \%\right)$ for 18 days. The impact of different scenarios, such as the synergetic heavy pollution induced by secondary aerosol formation and firework emissions, a dust event, and local traffic emissions on $N_{\mathrm{INP}}$ has been explored. $N_{\mathrm{INP}}$ was investigated in relation to $N_{500}$ and $m_{\mathrm{BC}}$. The relationships of $m_{\text {ammo }}$ with

$340 N_{\mathrm{INP}}$, as well as $\mathrm{PM}_{10-2.5}$ with $N_{\mathrm{INP}}$, during the dust event are also presented. The results show that $N_{\mathrm{INP}}$, as well as AF of ambient particles during dust event are substantially higher than all other scenarios. $N_{\mathrm{INP}}$ could reach $160 \mathrm{Z} \mathrm{L}^{-1}$ during the dust event, while it ranges from $10^{-1}$ to $10^{1} \mathrm{~L} \mathrm{~L}^{-1}$ on other days. AF during the dust event $(0.0036 \% \pm 0.0011 \%)$ is 20 to 30 times higher than clean $(0.0001 \% \pm 0.0001 \%)$ and heavily polluted days $(0.0002 \% \pm 0.0002 \%)$. During the dust event, $N_{\mathrm{INP}}$ and $m_{\mathrm{ammo}}$ exhibited synchronized variation, and $N_{\mathrm{INP}}$ exhibited slight dependence on $\mathrm{PM}_{10-2.5}\left(R^{2}=0.24\right)$. The parameterization proposed

345 by DeMott et al. (2010) predicts more than $60 \%$ of measured $N_{\text {INP }}$ within a factor of 2.5 during the dust event. Mass concentration measurements suggest that large amounts of aerosols containing chloride and BC appeared after the celebrations on Feb. $11^{\text {th }}$ and $26^{\text {th }}$ nights due to firework emission. Meanwhile, the stagnant and humid meteorology condition provides ideal condition for secondary aerosol formation. But there is no significant difference between $N_{\text {INP }}$ on heavily polluted and clean days, implying the urban aerosols from multiple sources with complex chemistry might not be effective INP. Besides,

350 the diurnal increase of $m_{\mathrm{BC}}$ from petrol passenger vehicle emissions during rush hours and from diesel truck emissions after 20:00 (UTC+8) on clean days does not lead to distinguishable higher $N_{\mathrm{INP}}$, implying that local traffic emission also has 
https://doi.org/10.5194/acp-2021-922

Preprint. Discussion started: 21 January 2022

(C) Author(s) 2022. CC BY 4.0 License.

(c) (1)

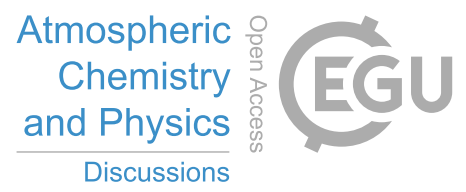

negligible impact on $N_{\mathrm{INP}}$. Our study reveals that mineral dusts, even though present in relatively low number concentration out of the high background particle number concentration, dominate immersion INP population in the urban environment. Furthermore, our results agree with previous literature from laboratory and field studies that atmospheric BC from both local 355 traffic and firework emissions has negligible effects on mixed-phase cloud formation, and that $N_{\text {INP }}$ is unaffected by heavy pollution. 
Appendix A Particle size and back trajectory analysis of the dust event

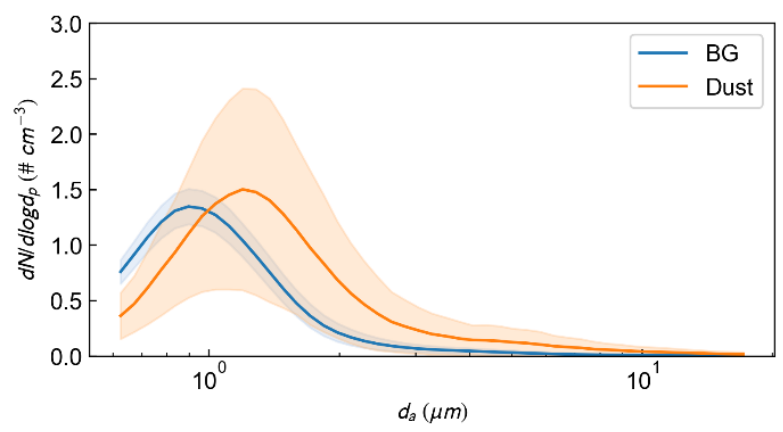

Figure A1. Aerodynamic diameter $\left(d_{a}\right)$ size distribution of particles before (BG) and during the dust event (Dust).

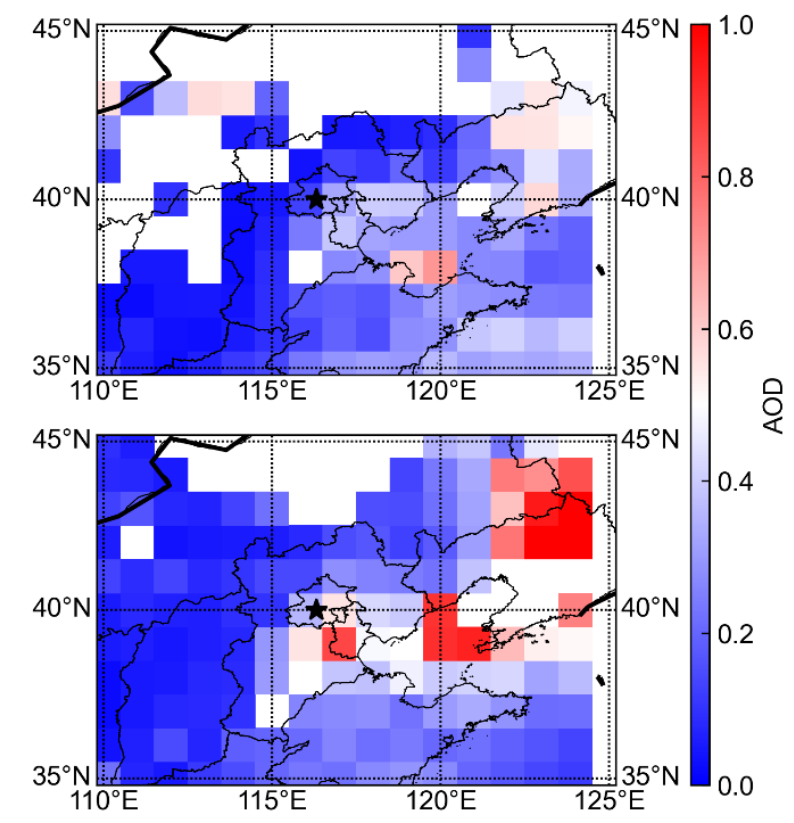

Figure A2. Aerosol optical depth (AOD) on Feb. $20^{\text {th }}$ (upper panel) and Feb. $21^{\text {st }}$ (lower panel) using MODIS Aqua Deep Blue Collection 6 aerosol data at $550 \mathrm{~nm}$ (Acker and Leptoukh, 2007). Sampling site is denoted with black star in each panel. 
https://doi.org/10.5194/acp-2021-922

Preprint. Discussion started: 21 January 2022

(c) Author(s) 2022. CC BY 4.0 License.

(c) (i)

\begin{tabular}{l} 
Atmospheric $\stackrel{\circ}{\circ}$ \\
Chemistry \\
and Physics \\
\hline Discussions
\end{tabular}

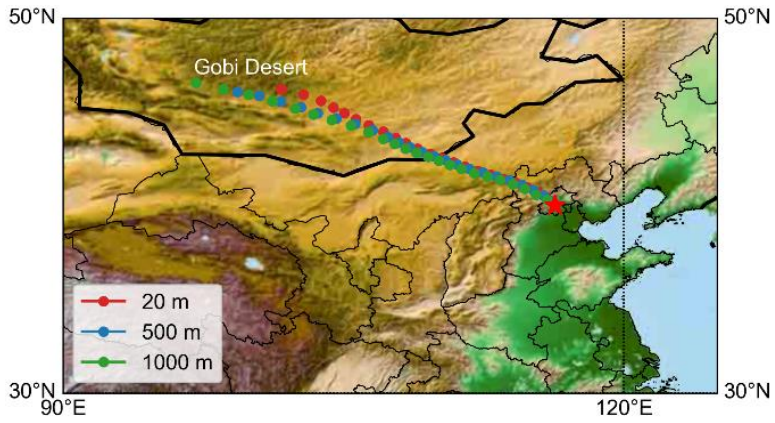

Figure A3. 24-hour back trajectory of the air parcel at the sampling site at three different heights $(20 \mathrm{~m}, 500 \mathrm{~m}$, and $1000 \mathrm{~m}$ above sea level). 


\section{Appendix B HINC lamina condition calibration}

HINC lamina condition calibration was performed by injection of $200 \mathrm{~nm}$ ammonium nitrate aqueous droplets into HINC at four lamina temperatures, i.e., $-45^{\circ} \mathrm{C},-40^{\circ} \mathrm{C},-35^{\circ} \mathrm{C}$, and $-30{ }^{\circ} \mathrm{C}$. HINC was operated in $R H$ scan mode during the calibration, in which HINC lamina temperature was maintained constant by varying the wall temperatures simultaneously, resulting in a temperature gradient and supersaturation in the chamber (Lacher et al., 2017). The $R H_{\mathrm{i}}$ within HINC lamina changed continuously from $100 \%$ to $160 \%$ at each lamina temperature. The concentration of the ammonium nitrate solution was 0.0025 mol L-1. The solution was atomized by a nebulizer (TSI Inc.) using 1.5 LPM nitrogen gas. The flow stream was dried to $R H_{\mathrm{w}}$ $<2 \%$ by passing through a $47 \mathrm{~cm}$ Nafion ${ }^{\text {TM }}$ dryer and was then size selected by a DMA (model 3081 long; TSI Inc.). Particle number concentration entering HINC was measured online by a CPC (model 3775; TSI Inc.).

Figure $\mathrm{B} 1$ shows the $\mathrm{AF}$ as a function of $R H_{\mathrm{w}}$ at $-30{ }^{\circ} \mathrm{C}$ for $200 \mathrm{~nm}$ ammonium nitrate aqueous droplets. Different $\mathrm{OPC}$ channel ( $>1 \mu \mathrm{m},>2 \mu \mathrm{m},>3 \mu \mathrm{m},>5 \mu \mathrm{m})$ are marked with different colors. It is worth noting that given the flow structure of HINC in this study (Sect. 2.2.3), only particles larger than $5 \mu \mathrm{m}$ detected by HINC OPC would be recognized as detectable ice crystals (below $-38^{\circ} \mathrm{C}$ ) or water droplets (above $-38^{\circ} \mathrm{C}$ ). As shown in Fig. B1, $200 \mathrm{~nm}$ ammonium nitrate aqueous droplets start to grow upon water saturation (black dots), followed by more rapid growth with increasing $R H_{\mathrm{w}}$ (grey dots). However, there is no growth in $>5 \mu \mathrm{m}$ channel until $R H_{\mathrm{w}}$ exceeds $106 \%$, corresponding to the presence of detectable water droplets larger than $5 \mu \mathrm{m}$. Therefore, HINC should be operated below $106 \%$ at $-30{ }^{\circ} \mathrm{C}$ to avoid erroneous count of large $(>5 \mu \mathrm{m})$ water droplets rather than ice crystals.

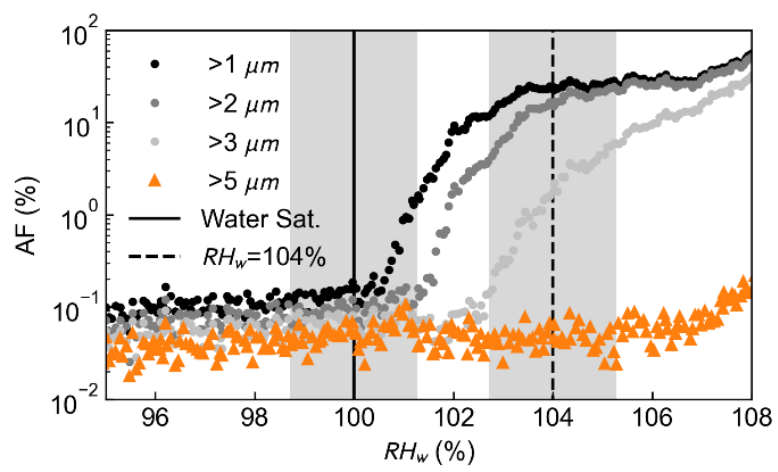

385 Figure B1. AF as a function of $\mathrm{RH}_{\mathrm{w}}$ at $-30{ }^{\circ} \mathrm{C}$ for $200 \mathrm{~nm}$ ammonium nitrate aqueous droplets detected in different $\mathrm{HINC}$ OPC channels. Vertical solid and dash black lines represent water saturation $\left(R H_{w}=100 \%\right)$ and $R H_{w}=104 \%$, respectively. Grey shading indicates the average variation of $\mathrm{RH}_{\mathrm{w}}$ along HINC lamina centerline.

Figure B2 shows the IN onset or water droplet survival points for $200 \mathrm{~nm}$ ammonium nitrate during the calibration. The IN onset or water droplet survival points are defined as the temperature and $R H$ when $0.1 \%$ of aerosols entering HINC are activated into detectable ice crystals or water droplets by HINC OPC in $>5 \mu \mathrm{m}$ channel. The blue and black solid lines represent water saturation $\left(R H_{\mathrm{w}}=100 \%\right)$ and homogeneous freezing threshold (Koop et al., 2000), respectively. The error bars in Fig. B1 represent one standard deviation of temperature and $R H_{\mathrm{i}}$ along HINC lamina centerline for each individual $R H_{\mathrm{i}}$ scan. During 
the calibration, the average variation of lamina $R H_{\mathrm{w}}$ was less than $1.2 \%$ (corresponding to a $1.8 \%$ variance of lamina $R H_{\mathrm{i}}$ ) . Lamina $R H_{\mathrm{w}}$ suffers larger variation as $R H$ increases, resulting in $R H_{\mathrm{w}}=108 \% \pm 2.1 \%$ at $-30{ }^{\circ} \mathrm{C}$. The variance of lamina temperature was below $0.2 \mathrm{~K}$ throughout the calibration process. As shown in Fig. B1, the IN onset point of $200 \mathrm{~nm}$ ammonium nitrate at $-40{ }^{\circ} \mathrm{C}$ lies on the calculated homogeneous freezing threshold. The IN onset at $-45^{\circ} \mathrm{C}$ exceeds the homogeneous freezing threshold by $3.5 \%$, yet still below water saturation line. When the lamina temperature is above $-38{ }^{\circ} \mathrm{C}$, water drops require $R H_{\mathrm{w}}$ substantially higher than $104 \%$ (dashed line) to be detected in the $>5 \mu \mathrm{m}$ OPC channel, as such we are confident that signals arising in the $>5 \mu \mathrm{m}$ OPC channel at $R H_{\mathrm{w}}=104 \%$ are due to ice crystal formation.

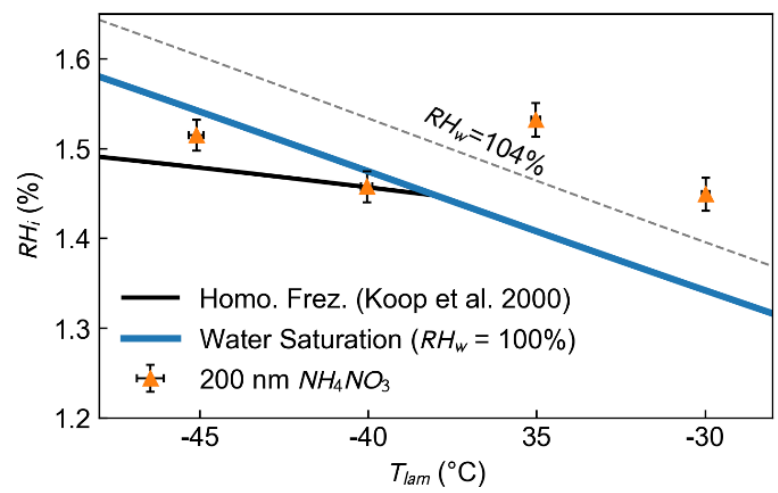

Figure B2. Phase diagram of the IN onset (below $-38{ }^{\circ} \mathrm{C}$ ) or water droplet detection in the $>5 \mu \mathrm{m}$ OPC channel $\left(\mathrm{above}-38{ }^{\circ} \mathrm{C}\right)$ for freezing or water droplet formation onto $200 \mathrm{~nm}$ dry diameter ammonium nitrate particles. The solid blue and black lines represent the water saturation line and the homogeneous freezing threshold of $200 \mathrm{~nm}$ aqueous droplets (Koop et al., 2000), respectively. The horizontal and vertical error bars represent the variation of temperature and $R_{\mathrm{i}}$ along HINC lamina centerline. 
https://doi.org/10.5194/acp-2021-922

Preprint. Discussion started: 21 January 2022

(c) Author(s) 2022. CC BY 4.0 License.

(c) (i)

\section{Appendix C Supplemental Information}
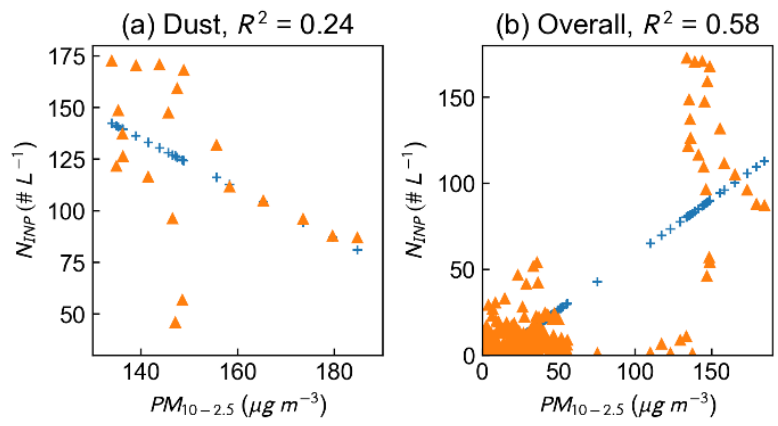

Figure C1: Correlations between the mass concentration difference of $\mathrm{PM}_{10}$ and $\mathrm{PM}_{2.5}\left(\mathrm{PM}_{10-2.5)}\right.$ and $N_{\text {INP }}$ in the (a) dust event and (b) observation. $R^{2}$ above each panel is the coefficient of determination for the linear regression fitting of the experiment data using OLS method. Blue markers indicate the predicted $N_{\text {INP }}$ using fitted linear regression parameters.
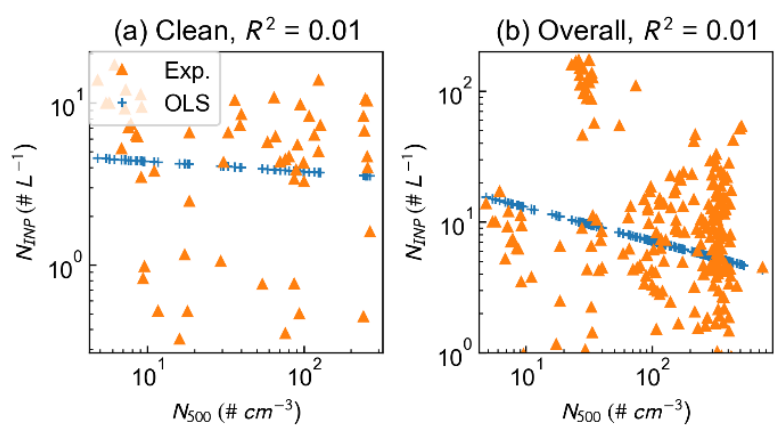

Figure C2: Correlations between $N_{500}$ and $N_{\text {INP }}$ for (a) clean days and (b) the observation. The $R^{2}$ above each panel is the coefficient of determination for the linear regression fitting of the experiment data using OLS method. Blue markers indicate the predicted $N_{\text {INP }}$ using fitted linear regression parameters. 
https://doi.org/10.5194/acp-2021-922

Preprint. Discussion started: 21 January 2022

(c) Author(s) 2022. CC BY 4.0 License.

(a) Clean

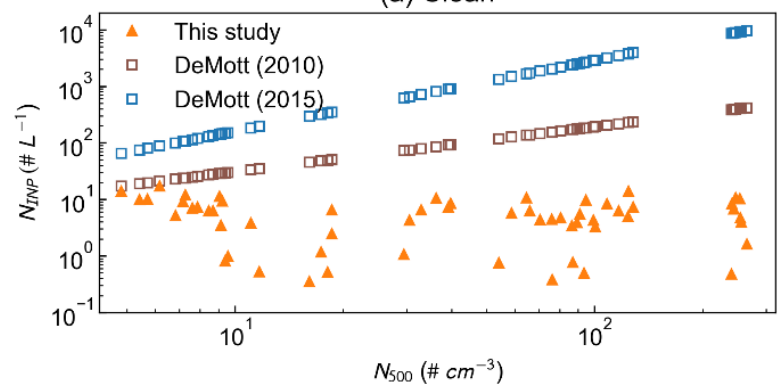

(b) Pollution

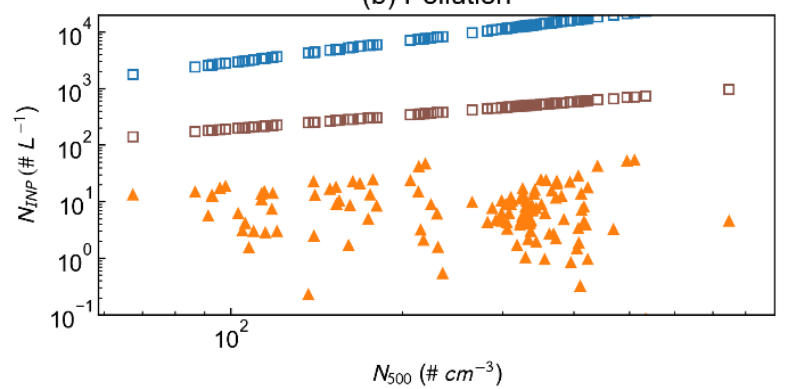

(c) Overall

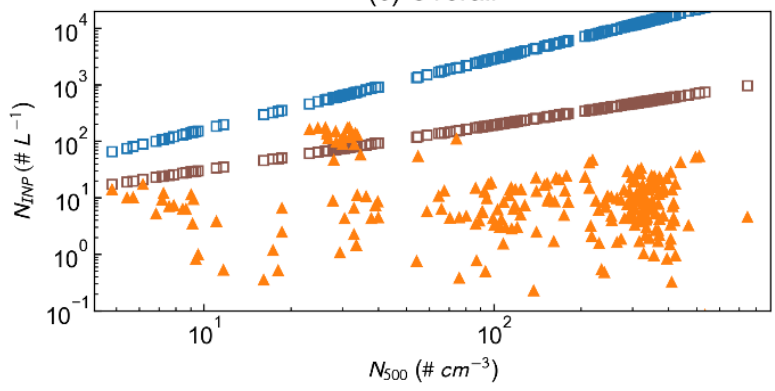

Figure C3: Inter-comparison of measured (solid orange triangles) and predicted (hollow blue and brown squares) $N_{\text {INP }}$ on clean (upper panel), heavy pollution (middle panel) days, and during the observation (lower panel). The prediction is based on the parameterizations that link $N_{\text {INP }}$ with the number concentration of particles larger than $500 \mathrm{~nm}\left(N_{500}\right)$ at a specific temperature (DeMott et al., 2010; DeMott et al., 2015).
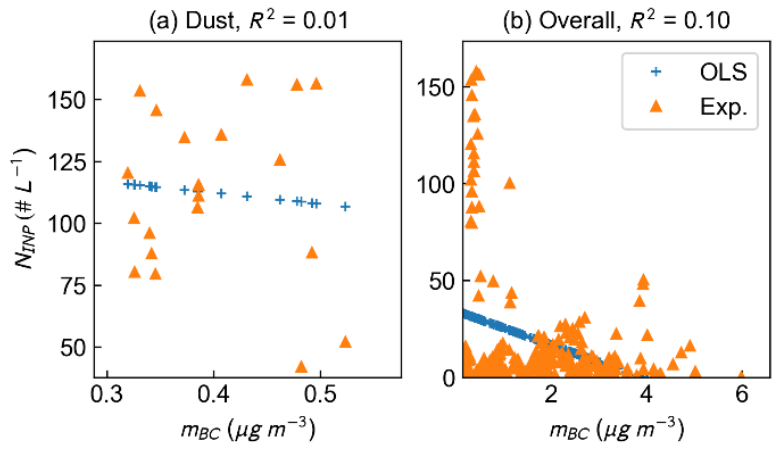
https://doi.org/10.5194/acp-2021-922

Preprint. Discussion started: 21 January 2022

(C) Author(s) 2022. CC BY 4.0 License.

Figure C4: Correlations between $m_{\mathrm{BC}}$ and $N_{\mathrm{INP}}$ during the (a) dust event and (b) observation. $R^{2}$ above each panel is the coefficient of determination for the linear regression fitting of the experiment data using OLS method. Blue markers indicate the predicted $N_{\text {INP }}$ using fitted linear regression parameters.

\section{Data availability}

425 Data inquires can be directed to the corresponding author (Zhijun Wu, zhijunwu@pku.edu.cn).

\section{Author Contributions}

CZ and ZW designed the experiments and methodology. CZ and JCC conducted the field observation. CZ, WZ, and LT performed aerosol chemical and size distribution analysis. CZ, JC, XP, and JCC calibrated HINC. SC and LZ provided the meteorology data. MH, ZW, ZAK, PT, and SG supervised the observation. CZ, ZW, and ZAK prepared the manuscript with input from all coauthors.

\section{Competing interests}

The authors declare no competing interests.

\section{Acknowledgments}

This work was supported by National Natural Science Foundation of China (NSFC, grant no. 42011530121, 91844301) and

435 Ministry of Science and Technology of China (MOST, grant no. 2019YFC0214701). Aerosol optical depth data used in this paper were produced with the Giovanni online data system, developed and maintained by the NASA GES DISC. ZAK acknowledges funding from the Atmospheric Physics Chair, ETH Zurich. 


\section{References}

440 Abbatt, J. P. D., Benz, S., Cziczo, D. J., Kanji, Z., Lohmann, U., and Möhler, O.: Solid Ammonium Sulfate Aerosols as Ice Nuclei: A Pathway for Cirrus Cloud Formation, Science, 313, 1770-1773, 10.1126/science.1129726, 2006.

Acker, J. G., and Leptoukh, G.: Online analysis enhances use of NASA Earth science data, Eos, Transactions American Geophysical Union, 88, 14-17, https://doi.org/10.1029/2007EO020003, 2007.

Adams, M. P., Tarn, M. D., Sanchez-Marroquin, A., Porter, G. C. E., O'Sullivan, D., Harrison, A. D., Cui, Z., Vergara-Temprado, J., 445 Carotenuto, F., Holden, M. A., Daily, M. I., Whale, T. F., Sikora, S. N. F., Burke, I. T., Shim, J. U., McQuaid, J. B., and Murray, B. J.: A Major Combustion Aerosol Event Had a Negligible Impact on the Atmospheric Ice-Nucleating Particle Population, Journal of Geophysical Research: Atmospheres, 125, e2020JD032938, https://doi.org/10.1029/2020JD032938, 2020.

Ansmann, A., Tesche, M., Althausen, D., Müller, D., Seifert, P., Freudenthaler, V., Heese, B., Wiegner, M., Pisani, G., Knippertz, P., and Dubovik, O.: Influence of Saharan dust on cloud glaciation in southern Morocco during the Saharan Mineral Dust Experiment, Journal of 450 Geophysical Research: Atmospheres, 113, https://doi.org/10.1029/2007JD008785, 2008.

Archuleta, C. M., DeMott, P. J., and Kreidenweis, S. M.: Ice nucleation by surrogates for atmospheric mineral dust and mineral dust/sulfate particles at cirrus temperatures, Atmospheric Chemistry \& Physics, 5, 2617-2634, 10.5194/acp-5-2617-2005, 2005.

Ardon-Dryer, K., and Levin, Z.: Ground-based measurements of immersion freezing in the eastern Mediterranean, Atmos. Chem. Phys., 14, 5217-5231, 10.5194/acp-14-5217-2014, 2014.

455 Atkinson, J. D., Murray, B. J., Woodhouse, M. T., Whale, T. F., Baustian, K. J., Carslaw, K. S., Dobbie, S., O'Sullivan, D., and Malkin, T. L.: The importance of feldspar for ice nucleation by mineral dust in mixed-phase clouds, Nature, 498, 355-358, 10.1038/nature12278, 2013.

Bergeron, T.: On the physics of cloud and precipitation, Proc. Fifth Assembly IUGG, Lisbon, Portugal, 1935, 156-178,

Bi, K., McMeeking, G. R., Ding, D. P., Levin, E. J. T., DeMott, P. J., Zhao, D. L., Wang, F., Liu, Q., Tian, P., Ma, X. C., Chen, Y. B., Huang, M. Y., Zhang, H. L., Gordon, T. D., and Chen, P.: Measurements of Ice Nucleating Particles in Beijing, China, Journal of Geophysical

Research: Atmospheres, 124, 8065-8075, https://doi.org/10.1029/2019JD030609, 2019.

Boose, Y., Kanji, Z. A., Kohn, M., Sierau, B., Zipori, A., Crawford, I., Lloyd, G., Bukowiecki, N., Herrmann, E., Kupiszewski, P., Steinbacher, M., and Lohmann, U.: Ice Nucleating Particle Measurements at 241 K during Winter Months at $3580 \mathrm{~m} \mathrm{MSL}$ in the Swiss Alps, Journal of the Atmospheric Sciences, 73, 2203-2228, 10.1175/jas-d-15-0236.1, 2016a.

Boose, Y., Sierau, B., García, M. I., Rodríguez, S., Alastuey, A., Linke, C., Schnaiter, M., Kupiszewski, P., Kanji, Z. A., and Lohmann, U.: Ice nucleating particles in the Saharan Air Layer, Atmos. Chem. Phys., 16, 9067-9087, 10.5194/acp-16-9067-2016, 2016b.

Boucher, O., Randall, D., Artaxo, P., Bretherton, C., Feingold, G., Forster, P., Kerminen, V.-M., Kondo, Y., Liao, H., Lohmann, U., Rasch, P., Satheesh, S. K., Sherwood, S., Stevens, B., and Zhang, X. Y.: Clouds and Aerosols. In: Climate Change 2013: The Physical Science Basis. Contribution of Working Group I to the Fifth Assessment Report of the Intergovernmental Panel on Climate Change [Stocker, T.F., D. Qin, G.-K. Plattner, M. Tignor, S.K. Allen, J. Boschung, A. Nauels, Y. Xia, V. Bex and P.M. Midgley (eds.)], Cambridge University Press, Cambridge, United Kingdom and New York, NY, USA., 2013.

Brunner, C., and Kanji, Z. A.: Continuous online monitoring of ice-nucleating particles: development of the automated Horizontal Ice Nucleation Chamber (HINC-Auto), Atmos. Meas. Tech., 14, 269-293, 10.5194/amt-14-269-2021, 2021.

Cantrell, W., and Heymsfield, A.: Production of Ice in Tropospheric Clouds: A Review, Bulletin of the American Meteorological Society, 86, 795-808, 10.1175/bams-86-6-795, 2005.

475 Cao, X., Zhang, X., Tong, D. Q., Chen, W., Zhang, S., Zhao, H., and Xiu, A.: Review on physicochemical properties of pollutants released from fireworks: environmental and health effects and prevention, Environmental Reviews, 26, 133-155, 10.1139/er-2017-0063, 2017.

Che, Y., Dang, J., Fang, W., Shen, X., Sun, J., Chen, Y., and Qian, Y.: Measurements of natural ice nucleating particles in Beijing in the spring of 2017, Atmospheric Environment, 200, 170-177, https://doi.org/10.1016/j.atmosenv.2018.12.020, 2019.

Che, Y., Zhang, J., Zhao, C., Fang, W., Xue, W., Yang, W., Ji, D., Dang, J., Duan, J., Sun, J., Shen, X., and Zhou, X.: A study on the characteristics of ice nucleating particles concentration and aerosols and their relationship in spring in Beijing, Atmospheric Research, 247, 105196, https://doi.org/10.1016/j.atmosres.2020.105196, 2021.

Chen, J., Wu, Z., Augustin-Bauditz, S., Grawe, S., Hartmann, M., Pei, X., Liu, Z., Ji, D., and Wex, H.: Ice-nucleating particle concentrations unaffected by urban air pollution in Beijing, China, Atmos. Chem. Phys., 18, 3523-3539, 10.5194/acp-18-3523-2018, 2018. 
Chen, J., Wu, Z., Chen, J., Reicher, N., Fang, X., Rudich, Y., and Hu, M.: Size-resolved atmospheric ice-nucleating particles during East Asian dust events, Atmos. Chem. Phys., 21, 3491-3506, 10.5194/acp-21-3491-2021, 2021.

Connolly, P. J., Möhler, O., Field, P. R., Saathoff, H., Burgess, R., Choularton, T., and Gallagher, M.: Studies of heterogeneous freezing by three different desert dust samples, Atmos. Chem. Phys., 9, 2805-2824, 10.5194/acp-9-2805-2009, 2009.

Corbin, J. C., Rehbein, P. J. G., Evans, G. J., and Abbatt, J. P. D.: Combustion particles as ice nuclei in an urban environment: Evidence from single-particle mass spectrometry, Atmospheric Environment, 51, 286-292, https://doi.org/10.1016/j.atmosenv.2012.01.007, 2012.

490 Cziczo, D. J., Froyd, K. D., Hoose, C., Jensen, E. J., Diao, M., Zondlo, M. A., Smith, J. B., Twohy, C. H., and Murphy, D. M.: Clarifying the dominant sources and mechanisms of cirrus cloud formation, Science, 340, 1320-1324, 2013.

de Boer, G., Morrison, H., Shupe, M. D., and Hildner, R.: Evidence of liquid dependent ice nucleation in high-latitude stratiform clouds from surface remote sensors, Geophysical Research Letters, 38, https://doi.org/10.1029/2010GL046016, 2011.

DeMott, P. J., Cziczo, D. J., Prenni, A. J., Murphy, D. M., Kreidenweis, S. M., Thomson, D. S., Borys, R., and Rogers, D. C.: Measurements of the concentration and composition of nuclei for cirrus formation, Proceedings of the National Academy of Sciences, 100, 14655-14660, 10.1073/pnas.2532677100, 2003.

DeMott, P. J., Prenni, A. J., Liu, X., Kreidenweis, S. M., Petters, M. D., Twohy, C. H., Richardson, M. S., Eidhammer, T., and Rogers, D. C.: Predicting global atmospheric ice nuclei distributions and their impacts on climate, Proceedings of the National Academy of Sciences, 107, 11217-11222, 10.1073/pnas.0910818107, 2010.

500 DeMott, P. J., Prenni, A. J., McMeeking, G. R., Sullivan, R. C., Petters, M. D., Tobo, Y., Niemand, M., Moehler, O., Snider, J. R., Wang, Z., and Kreidenweis, S. M.: Integrating laboratory and field data to quantify the immersion freezing ice nucleation activity of mineral dust particles, Atmospheric Chemistry and Physics, 15, 393-409, 10.5194/acp-15-393-2015, 2015.

Field, P. R., and Heymsfield, A. J.: Importance of snow to global precipitation, Geophysical Research Letters, 42, 9512-9520, https://doi.org/10.1002/2015GL065497, 2015.

505 Findeisen, W.: Kolloid-meteorologische Vorgänge bei Neiderschlags-bildung, Meteor. Z, 55, 121-133, 1938.

Heymsfield, A. J., Schmitt, C., Chen, C.-C.-J., Bansemer, A., Gettelman, A., Field, P. R., and Liu, C.: Contributions of the Liquid and Ice Phases to Global Surface Precipitation: Observations and Global Climate Modeling, Journal of the Atmospheric Sciences, 77, 2629-2648, 10.1175/JAS-D-19-0352.1, 2020.

Hoose, C., and Möhler, O.: Heterogeneous ice nucleation on atmospheric aerosols: a review of results from laboratory experiments, Atmospheric Chemistry and Physics, 12, 9817-9854, 10.5194/acp-12-9817-2012, 2012.

Hua, Y., Wang, S., Jiang, J., Zhou, W., Xu, Q., Li, X., Liu, B., Zhang, D., and Zheng, M.: Characteristics and sources of aerosol pollution at a polluted rural site southwest in Beijing, China, Science of The Total Environment, 626, 519-527, https://doi.org/10.1016/j.scitotenv.2018.01.047, 2018.

Jiang, Q., Sun, Y. L., Wang, Z., and Yin, Y.: Aerosol composition and sources during the Chinese Spring Festival: fireworks, secondary aerosol, and holiday effects, Atmos. Chem. Phys., 15, 6023-6034, 10.5194/acp-15-6023-2015, 2015.

Kanji, Z. A., and Abbatt, J. P. D.: Laboratory studies of ice formation via deposition mode nucleation onto mineral dust and n-hexane soot samples, Journal of Geophysical Research, 111, 10.1029/2005jd006766, 2006.

Kanji, Z. A., and Abbatt, J. P. D.: The University of Toronto Continuous Flow Diffusion Chamber (UT-CFDC): A Simple Design for Ice Nucleation Studies, Aerosol Science and Technology, 43, 730-738, 10.1080/02786820902889861, 2009.

520 Kanji, Z. A., Ladino, L. A., Wex, H., Boose, Y., Burkert-Kohn, M., Cziczo, D. J., and Krämer, M.: Overview of Ice Nucleating Particles, Meteorological Monographs, 58, 1.1-1.33, 10.1175/amsmonographs-d-16-0006.1, 2017.

Kanji, Z. A., Welti, A., Corbin, J. C., and Mensah, A. A.: Black Carbon Particles Do Not Matter for Immersion Mode Ice Nucleation, Geophysical Research Letters, 47, e2019GL086764, 10.1029/2019g1086764, 2020.

Khlystov, A., Stanier, C., and Pandis, S. N.: An Algorithm for Combining Electrical Mobility and Aerodynamic Size Distributions Data 525 when Measuring Ambient Aerosol Special Issue of Aerosol Science and Technology on Findings from the Fine Particulate Matter Supersites Program, Aerosol Science and Technology, 38, 229-238, 10.1080/02786820390229543, 2004.

Kittelson, D. B.: Engines and nanoparticles: a review, Journal of Aerosol Science, 29, 575-588, https://doi.org/10.1016/S00218502(97)10037-4, 1998. 
Knopf, D. A., Wang, B., Laskin, A., Moffet, R. C., and Gilles, M. K.: Heterogeneous nucleation of ice on anthropogenic organic particles collected in Mexico City, Geophysical Research Letters, 37, 10.1029/2010g1043362, 2010.

Kong, S. F., Li, L., Li, X. X., Yin, Y., Chen, K., Liu, D. T., Yuan, L., Zhang, Y. J., Shan, Y. P., and Ji, Y. Q.: The impacts of firework burning at the Chinese Spring Festival on air quality: insights of tracers, source evolution and aging processes, Atmos. Chem. Phys., 15, 2167-2184, 10.5194/acp-15-2167-2015, 2015.

Koop, T., Luo, B., Tsias, A., and Peter, T.: Water activity as the determinant for homogeneous ice nucleation in aqueous solutions, Nature, 406, 611, 10.1038/35020537, 2000.

Korolev, A., McFarquhar, G., Field, P. R., Franklin, C., Lawson, P., Wang, Z., Williams, E., Abel, S. J., Axisa, D., Borrmann, S., Crosier, J., Fugal, J., Krämer, M., Lohmann, U., Schlenczek, O., Schnaiter, M., and Wendisch, M.: Mixed-Phase Clouds: Progress and Challenges, Meteorological Monographs, 58, 5.1-5.50, 10.1175/AMSMONOGRAPHS-D-17-0001.1, 2017.

Kumar, A., Marcolli, C., Luo, B., and Peter, T.: Ice nucleation activity of silicates and aluminosilicates in pure water and aqueous solutions

- Part 1: The K-feldspar microcline, Atmos. Chem. Phys., 18, 7057-7079, 10.5194/acp-18-7057-2018, 2018.

Kumar, A., Marcolli, C., and Peter, T.: Ice nucleation activity of silicates and aluminosilicates in pure water and aqueous solutions - Part 3: Aluminosilicates, Atmos. Chem. Phys., 19, 6059-6084, 10.5194/acp-19-6059-2019, 2019.

Lacher, L., Lohmann, U., Boose, Y., Zipori, A., Herrmann, E., Bukowiecki, N., Steinbacher, M., and Kanji, Z. A.: The Horizontal Ice Nucleation Chamber (HINC): INP measurements at conditions relevant for mixed-phase clouds at the High Altitude Research Station 545 Jungfraujoch, Atmos. Chem. Phys., 17, 15199-15224, 10.5194/acp-17-15199-2017, 2017.

Lei, L., Zhou, W., Chen, C., He, Y., Li, Z., Sun, J., Tang, X., Fu, P., Wang, Z., and Sun, Y.: Long-term characterization of aerosol chemistry in cold season from 2013 to 2020 in Beijing, China, Environmental Pollution, 268, 115952, https://doi.org/10.1016/j.envpol.2020.115952, 2021.

Li, J., Gao, W., Cao, L., Xiao, Y., Zhang, Y., Zhao, S., Liu, Z., Liu, Z., Tang, G., Ji, D., Hu, B., Song, T., He, L., Hu, M., and Wang, Y.: 550 Significant changes in autumn and winter aerosol composition and sources in Beijing from 2012 to 2018: Effects of clean air actions, Environmental Pollution, 268, 115855, https://doi.org/10.1016/j.envpol.2020.115855, 2021.

Lin, J., An, J., Qu, Y., Chen, Y., Li, Y., Tang, Y., Wang, F., and Xiang, W.: Local and distant source contributions to secondary organic aerosol in the Beijing urban area in summer, Atmospheric Environment, 124, 176-185, https://doi.org/10.1016/j.atmosenv.2015.08.098, 2016.

555 Lüönd, F., Stetzer, O., Welti, A., and Lohmann, U.: Experimental study on the ice nucleation ability of size-selected kaolinite particles in the immersion mode, Journal of Geophysical Research: Atmospheres, 115, 10.1029/2009jd012959, 2010.

Mahrt, F., Marcolli, C., David, R. O., Gronquist, P., Meier, E. J. B., Lohmann, U., and Kanji, Z. A.: Ice nucleation abilities of soot particles determined with the Horizontal Ice Nucleation Chamber, Atmospheric Chemistry and Physics, 18, 13363-13392, 10.5194/acp-18-133632018, 2018.

560 Mülmenstädt, J., Sourdeval, O., Delanoë, J., and Quaas, J.: Frequency of occurrence of rain from liquid-, mixed-, and ice-phase clouds derived from A-Train satellite retrievals, Geophysical Research Letters, 42, 6502-6509, https://doi.org/10.1002/2015GL064604, 2015.

Murray, B. J., O'Sullivan, D., Atkinson, J. D., and Webb, M. E.: Ice nucleation by particles immersed in supercooled cloud droplets, Chem. Soc. Rev., 41, 6519-6554, 10.1039/c2cs35200a, 2012.

Murray, B. J., Wilson, T. W., Dobbie, S., Cui, Z., Al-Jumur, S. M. R. K., Möhler, O., Schnaiter, M., Wagner, R., Benz, S., Niemand, M.,

565 Saathoff, H., Ebert, V., Wagner, S., and Kärcher, B.: Heterogeneous nucleation of ice particles on glassy aerosols under cirrus conditions, Nature Geoscience, 3, 233-237, 10.1038/ngeo817, 2010.

Nichman, L., Wolf, M., Davidovits, P., Onasch, T. B., Zhang, Y., Worsnop, D. R., Bhandari, J., Mazzoleni, C., and Cziczo, D. J.: Laboratory study of the heterogeneous ice nucleation on black-carbon-containing aerosol, Atmos. Chem. Phys., 19, 12175-12194, 10.5194/acp-1912175-2019, 2019.

570 Pruppacher, H. R., and Klett, J. D.: Microphysics of Clouds and Precipitation, 2 ed., Atmospheric and Oceanographic Sciences Library, 18, Springer Netherlands, XXII, 954 pp., 2010.

Raza, M., Chen, L., Leach, F., and Ding, S.: A Review of Particulate Number (PN) Emissions from Gasoline Direct Injection (GDI) Engines and Their Control Techniques, Energies, 11, 10.3390/en11061417, 2018. 
Rogers, D. C., DeMott, P. J., Kreidenweis, S. M., and Chen, Y.: Measurements of ice nucleating aerosols during SUCCESS, Geophysical Research Letters, 25, 1383-1386, https://doi.org/10.1029/97GL03478, 1998.

Schill, G. P., DeMott, P. J., Emerson, E. W., Rauker, A. M. C., Kodros, J. K., Suski, K. J., Hill, T. C. J., Levin, E. J. T., Pierce, J. R., Farmer, D. K., and Kreidenweis, S. M.: The contribution of black carbon to global ice nucleating particle concentrations relevant to mixed-phase clouds, Proceedings of the National Academy of Sciences, 117, 22705-22711, 10.1073/pnas.2001674117, 2020.

Schill, G. P., Jathar, S. H., Kodros, J. K., Levin, E. J. T., Galang, A. M., Friedman, B., Link, M. F., Farmer, D. K., Pierce, J. R., Kreidenweis,

580 S. M., and DeMott, P. J.: Ice-nucleating particle emissions from photochemically aged diesel and biodiesel exhaust, Geophysical Research Letters, 43, 5524-5531, doi:10.1002/2016GL069529, 2016.

Seinfeld, J. H., and Pandis, S. N.: Atmospheric chemistry and physics: from air pollution to climate change, John Wiley \& Sons, 2016.

Silber, I., Fridlind, A. M., Verlinde, J., Ackerman, A. S., Cesana, G. V., and Knopf, D. A.: The prevalence of precipitation from polar supercooled clouds, Atmos. Chem. Phys., 21, 3949-3971, 10.5194/acp-21-3949-2021, 2021.

585 Sun, Y., Du, W., Fu, P., Wang, Q., Li, J., Ge, X., Zhang, Q., Zhu, C., Ren, L., Xu, W., Zhao, J., Han, T., Worsnop, D. R., and Wang, Z.: Primary and secondary aerosols in Beijing in winter: sources, variations and processes, Atmos. Chem. Phys., 16, 8309-8329, 10.5194/acp16-8309-2016, 2016.

Vali, G., DeMott, P. J., Möhler, O., and Whale, T. F.: Technical Note: A proposal for ice nucleation terminology, Atmos. Chem. Phys., 15, 10263-10270, 10.5194/acp-15-10263-2015, 2015.

590 Wang, Y., Wu, Z., Ma, N., Wu, Y., Zeng, L., Zhao, C., and Wiedensohler, A.: Statistical analysis and parameterization of the hygroscopic growth of the sub-micrometer urban background aerosol in Beijing, Atmospheric Environment, 175, 184-191, https://doi.org/10.1016/j.atmosenv.2017.12.003, 2018.

Wegener, A.: Thermodynamik der Atnwsphäre, J. A. Barth, Leipzig, 331 pp., 1911.

Welti, A., Lüönd, F., Stetzer, O., and Lohmann, U.: Influence of particle size on the ice nucleating ability of mineral dusts, Atmos. Chem. Phys., 9, 6705-6715, 10.5194/acp-9-6705-2009, 2009.

Whale, T. F., Holden, M. A., Wilson, Theodore W., O'Sullivan, D., and Murray, B. J.: The enhancement and suppression of immersion mode heterogeneous ice-nucleation by solutes, Chemical Science, 9, 4142-4151, 10.1039/C7SC05421A, 2018.

Wolf, M. J., Goodell, M., Dong, E., Dove, L. A., Zhang, C., Franco, L. J., Shen, C., Rutkowski, E. G., Narducci, D. N., Mullen, S., Babbin, A. R., and Cziczo, D. J.: A link between the ice nucleation activity and the biogeochemistry of seawater, Atmos. Chem. Phys., 20, 15341600 15356, 10.5194/acp-20-15341-2020, 2020a.

Wolf, M. J., Zhang, Y., Zawadowicz, M. A., Goodell, M., Froyd, K., Freney, E., Sellegri, K., Rösch, M., Cui, T., Winter, M., Lacher, L., Axisa, D., DeMott, P. J., Levin, E. J. T., Gute, E., Abbatt, J., Koss, A., Kroll, J. H., Surratt, J. D., and Cziczo, D. J.: A biogenic secondary organic aerosol source of cirrus ice nucleating particles, Nature communications, 11, 4834, 10.1038/s41467-020-18424-6, 2020b.

Wu, C., Zhang, S., Wang, G., Lv, S., Li, D., Liu, L., Li, J., Liu, S., Du, W., Meng, J., Qiao, L., Zhou, M., Huang, C., and Wang, H.: Efficient Heterogeneous Formation of Ammonium Nitrate on the Saline Mineral Particle Surface in the Atmosphere of East Asia during Dust Storm Periods, Environmental Science \& Technology, 54, 15622-15630, 10.1021/acs.est.0c04544, 2020.

Wu, Z., Chen, J., Wang, Y., Zhu, Y., Liu, Y., Yao, B., Zhang, Y., and Hu, M.: Interactions between water vapor and atmospheric aerosols have key roles in air quality and climate change, National Science Review, 5, 452-454, 10.1093/nsr/nwy063, 2018.

Zhang, C., Zhang, Y., Wolf, M. J., Nichman, L., Shen, C., Onasch, T. B., Chen, L., and Cziczo, D. J.: The effects of morphology, mobility 610 size, and secondary organic aerosol (SOA) material coating on the ice nucleation activity of black carbon in the cirrus regime, Atmos. Chem. Phys., 20, 13957-13984, 10.5194/acp-20-13957-2020, 2020a.

Zhang, S., Wu, Y., Yan, H., Du, X., Max Zhang, K., Zheng, X., Fu, L., and Hao, J.: Black carbon pollution for a major road in Beijing: Implications for policy interventions of the heavy-duty truck fleet, Transportation Research Part D: Transport and Environment, 68, 110121, https://doi.org/10.1016/j.trd.2017.07.013, 2019.

615 Zhang, X., Zhang, K., Liu, H., Lv, W., Aikawa, M., Liu, B., and Wang, J.: Pollution sources of atmospheric fine particles and secondary aerosol characteristics in Beijing, Journal of Environmental Sciences, 95, 91-98, https://doi.org/10.1016/j.jes.2020.04.002, 2020b.

Zhao, B., Wang, Y., Gu, Y., Liou, K. N., Jiang, J. H., Fan, J., Liu, X., Huang, L., and Yung, Y. L.: Ice nucleation by aerosols from anthropogenic pollution, Nature geoscience, 12, 602-607, 10.1038/s41561-019-0389-4, 2019. 